UC-4

Reporting Date: July 1975

Issued: October 1975

\title{
Accurate Defermination of Impurity Concentrations in Plutonium Metals by Statistical Evaluation of Analytical Data
}

by

C. J. Martell

G. L. Tietjen

M. M. Horita 
Printed in the United Staten of America. Available trom National Tochnical Inlormution Service

US Depariment of Commerct

5285 Port Royal Road

Springtiald, VA 2015

Price: Printed Copy 4.00 Microfiche $\$ 2.25$

This report wes prepand as an nocount of wort spanenes

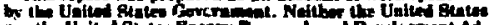

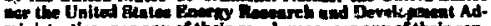

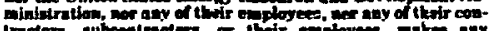

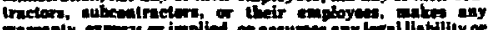

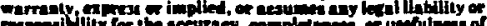

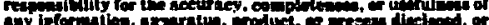

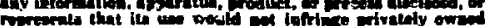
Nifis. 
Thes itpurt wh preporice

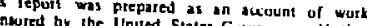

the United States not the United Sint Nether

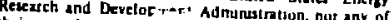

their employses. ror any of thes contractors

wabroninactur, ot theis emiployees, maks any

warronty. express of impled, or csumes any leal

or ury or reponibility for the accuracy, completener

procest dies of any information, apparal us, produrt ot

infrnge pnvately owmed riests.

\title{
ACCURATE DETERMINATION OF IMPURITY CONCENTRATIONS IN PIUTONIUM METALS BY STATISTICAL EVALUATION OF ANALYTICAL DATA
}

by

\author{
C. J. Martell, G. L. Tietjen, and M. M. Horita
}

\begin{abstract}
Analytical data from a plutonium-metal exchange program conducted by six ERDA laboratories are statistically evaluated. The objective is an accurate determination of five metal impurities (aluminum, chromium, iron, nickel, silicon) in each of three plutonium metals by using data from four analytical methods. The statistical evaluation yields the weighted mean and its standard deviation for each method, plutonium metal, and impurity, using a procedure that minimizes the effect of outliers by assigning zero weights to the most extreme values and variable weights to the remaining data. Where possible, weighted means from the various analytical methods are pooled.
\end{abstract}

\section{INTHODUCTION}

Well-characterized standard materials are invaluable for making accurate analytica! measurements in any field, and in the nuclear field well-characterized plutonium metals have not been availabie. Data are presented here for three standard plutonium metals accurately rharacterized according to content of five impurities: aluminum, chromium, iron, nickel, and silicon.

Data from a plutonium-metal exchange program conducted by six ERDA laboratories have been analyzed, and three plutonium metals, identified as $H, R$, and $P$, have been carefully characterized. These weil-characterized plutonium metals should be useful in resolving measurement differences among laboratories, improving current analytical methods, developing new measurement capabilities, and providing data with which to resolve shipperreceiver differences.

By using these standard plutonium metals, a laboratory can evaluate its analytical performance and take corrective action if its analytical results are in error. Also, work is under way using these three plutonium metals in evaluating several types of $\mathrm{PuO}_{2}$ emission spectroscopy standards.

Data from the plutonium-metal exchange program, recorded quarterly from December 1971 to December 1974, will be considered here. Unfortunately, different reporting procedures were used during this period, and the same procedure was not used by all the laboratories at any given time. The effect of these differing procedures will be discussed later.

Four methods of analysis were used: emission spectroscopy; chemical method; spark source mass spectroscopy; and atomic absorption. Of the four, only emission spectroscopy can be used to determine all five impurity elements in all three plutonium metals. The chemical method determines only iron. Emission spectroscopy and the chemical method have been used in the exchange program longer than the other methods and so have contributed the largest number of values to this report.

Spark source mass spectroscopy has been used only at the Rocky Flats laboratory. For calibration purposes, spark source spectroscopy uses the iron value determined by atomic absorption for a given 
sample and gives values for aluminum, chromium, nickel, and silicon.

Atomic absorption has been used in the exchange program for only a short time. The impurities determined by atomic absorption include aluminum. chromium, nickel, and iron. Rocky Flats has also reported a small number of values for silicon.

A secondary purpose of this report is to suggest a statistical treatment for future plutonium-metal exchange data that may lead to a consensus on impurity concentrations while a supply of a particular batch of plutonium metal still exists. These wellcharacterized metals could be considered "certified" plutonium metals. Additional determinations, such as those for carbon, gallium, plutonium, and uranium. could also be so treated.

\section{STATISTICAL METHODOLOGY}

For each impurity, plutonium metal, and analytical method, the data from the six participating laboratories are combined, and from 8 to 127 data values are given in the initial evaluation. $P$. metal iron data taken before December 1972 by emission spectroscopy at two of the laboratories showed a high bias and were deleted. The two laboratories had been using $\mathrm{PuO}_{2}$ obtained from the direct ignition of plutonium metal. However, a study $^{1}$ made during 1972 shor ad that high iron values are obtained from $P$-metal when the particle size of the $\mathrm{PuO}_{2}$ is not controlled. When the laboratories began to control $\mathrm{PuO}_{2}$ particle size, the high bias for iron was no longer observed.

Because the data come from several laboratories analytical methods, and reporting procedures, outliers are likely to be present. It is difficult to determine an underlying distribution for the data. Cerrainly the assumption of normality is not appropriate. How, then, does one best estimate the mean under these circumsiances? An estimator that is not very sensitive to the underlying distribution is said to be "robust." We believe that the method destribed in this report is the best method of robust estimation ${ }^{2}$ to date. It makes use of weighted means and prescribes how the weights are to be assigned. Standard deviations of the weighted means are also calculated, but heir properties are not yet well known.

If $x_{i}, i=1, \ldots, n$,denotes the $i$-th observation and $w_{i}$ a weighting factor for the $i-t$ th observation, the weighted mean is defined as

$$
\bar{x}_{w}=\frac{\sum_{i=1}^{n} w_{1} x_{i}}{\sum_{i=1}^{n} w_{i}} .
$$

Let $r_{i}=\left|x_{i}-X_{w}\right|$ denote the absolute value of the $i$-th residual and define $S$ to be the median residual. The weights themselves are defined iteratively as $w_{i}=$ $1 / r_{i} \sin \left(r_{i} / c S\right)$, where $c$ is an arbitrary scaling factor ( $c=1$ in this report). Ten iterations are made starting with unit weights. This method assigns zero weights to observations when $r_{i}>\pi S$, large weights to observations with small residuals, and small weights to observations with large residuals.

The standard deviation of the weighted mean, $\mathrm{S}_{\mathrm{X}_{\boldsymbol{w}}}$ is then calculated for each impurity in each plutonium metal and for each analytical procedure by

$$
s_{\bar{x}_{w}}=\left[\frac{\sum_{i=1}^{n^{\prime}} r_{i}^{2} w_{i}}{\left(n^{\prime}-1\right) \sum_{i=1}^{\pi} w_{i}}\right]^{1 / 2}
$$

where $n^{\prime}$ is the number of observations receiving nonzero weights.

The computer program, data, residuals, weights, and various means and standard deviations are given in Appendixes I and II.

\section{RESULTS}

The weighted mean and the standard deviation of the weighted mean for each impurity, plutonium metal, and analytical procedure are summarized in Table I.

A weighted mean and its standard deviation, botil pooled from the analytical methods, are shown in Table II. These are computed as follows:

$$
\bar{x}_{v}(\text { pooled })=\frac{n_{1}^{\prime} \bar{x}_{w_{1}}+n_{2}^{\prime} \bar{x}_{w_{2}}+n_{3}^{\prime} \bar{x}_{w_{3}}}{n_{1}^{\prime}+n_{2}^{\prime}+n_{3}^{\prime}}
$$


TABLE I

WEIGHTED MEAN AND ITS STANDARD DEVIATION FOR EACH IMPURITY FROM EACH ANALYTICAL METHOD (micrograms per gram of plutonium metal)

\begin{tabular}{|c|c|c|c|c|c|}
\hline Impurity & $\begin{array}{c}\text { Plutonium } \\
\text { Metal } \\
\end{array}$ & $\begin{array}{c}\text { Emission } \\
\text { Spectroscopy } \\
\end{array}$ & $\begin{array}{c}\text { Spark Source } \\
\text { Mass Spectroscopy } \\
\end{array}$ & $\begin{array}{c}\text { Atomic } \\
\text { Alssorption } \\
\end{array}$ & $\begin{array}{c}\text { Chemical } \\
\text { Method } \\
\end{array}$ \\
\hline Aluminum & $\begin{array}{l}\mathrm{H} \\
\mathrm{R} \\
\mathrm{P}\end{array}$ & $\begin{array}{r}174.6 \pm 2.9 \\
22.5 \pm 0.5 \\
55.5 \pm 1.3\end{array}$ & $\begin{array}{c}177.5 \pm 10.5 \\
16.2 \pm 0.4 \\
53.7 \pm 1.8\end{array}$ & $\begin{array}{c}183.5 \pm 2.5 \\
34.6 \pm 2.4 \\
--\end{array}$ & $\begin{array}{l}\cdots \\
\cdots \\
\cdots\end{array}$ \\
\hline Chromium & $\begin{array}{l}\mathbf{H} \\
\mathbf{R} \\
\mathbf{P}\end{array}$ & $\begin{array}{r}196.7 \pm 2.8 \\
45.0 \pm 0.9 \\
48.6 \pm 0.9\end{array}$ & $\begin{array}{r}217.5 \pm 3.7 \\
38.0 \pm 1.5 \\
43.9 \pm 2.7\end{array}$ & $\begin{aligned} 171.5 & \pm 1.1 \\
48.9 & \pm 1.0 \\
-- & \end{aligned}$ & $\begin{array}{l}\cdots \\
\cdots \\
\cdots\end{array}$ \\
\hline Nickel & $\begin{array}{l}\mathrm{H} \\
\mathrm{R} \\
\mathrm{P}\end{array}$ & $\begin{array}{l}441.0 \pm 5.2 \\
101.3 \pm 1.2 \\
137.2 \pm 1.5\end{array}$ & $\begin{array}{r}449.1 \pm 3.6 \\
94.2 \pm 2.4 \\
135.4 \pm 5.4\end{array}$ & $\begin{array}{c}437.5 \pm 3.1 \\
108.1 \pm 1.6 \\
\ldots\end{array}$ & $\begin{array}{l}\cdots \\
\cdots \\
\cdots\end{array}$ \\
\hline Silicon & $\begin{array}{l}\mathrm{H} \\
\mathbf{R} \\
\mathbf{P}\end{array}$ & $\begin{array}{r}180.8 \pm 3.9 \\
34.6 \pm 1.0 \\
24.4 \pm 0.8\end{array}$ & $\begin{array}{c}222.4 \pm 20.2 \\
35.8 \pm 1.1 \\
36.2 \pm 2.2\end{array}$ & $\begin{array}{r}129.7 \pm 3.6 \\
32.6 \pm 0.9 \\
--\end{array}$ & $\begin{array}{l}\cdots- \\
\cdots- \\
\cdots-\end{array}$ \\
\hline Iron & $\begin{array}{l}\mathbf{H} \\
\mathbf{R} \\
\mathbf{P}\end{array}$ & $\begin{array}{l}962.8 \pm 10.5 \\
111.4 \pm 2.2 \\
318.1 \pm 5.5\end{array}$ & $\begin{array}{l}\cdots \\
--\end{array}$ & $\begin{array}{c}915.7 \pm 11.4 \\
112.9 \pm 2.1 \\
--\end{array}$ & $\begin{array}{l}947.0 \pm 4.3 \\
114.4 \pm 2.3 \\
326.4 \pm 2.1\end{array}$ \\
\hline
\end{tabular}

TABLE II

WEIGHTED MEAN AND ITS STANDAIRD DEVIATION FOR EACH IMPURITY POOLED FROM SEVERAL ANAL YTICAL METHODS ${ }^{\circledR}$ (micrograms per gram of plutonium metal)

Impurity

Aluminum

Chromiunı

Nickel

Silicon

Iron

$-\frac{H}{176.3 \pm 4.2}$
$196.7 \pm 2.8^{b}$
$440.9 \pm 4.7$
$185.8 \pm 7.7^{d}$
$949.2 \pm 8.8$

\section{Plutonium Metals}

\begin{tabular}{|c|c|}
\hline $\mathbf{R}$ & $\mathbf{P}$ \\
\hline $22.5 \pm 0.5^{b}$ & $55.3 \pm 1.3$ \\
\hline $46.1 \pm 0.9^{c}$ & $48.2 \pm 1.1$ \\
\hline $102.5 \pm 1.4$ & $137.0 \pm 2.1$ \\
\hline $34.5 \pm 1.0$ & $24.4 \pm 0.8^{b}$ \\
\hline $112.7 \pm 2.2$ & $322.0 \pm 4.2$ \\
\hline
\end{tabular}

adata from all analytical methods are combined to compute the pooled weighted means and pooled standard deviations of the weighted means unless indicated by superscripts.

based on emission spectroscopy.

Based on emission spectroscopy and atomic absorption.

Based on ernission spectroscopy and spark source mass spectroscopy. 
and

$s_{\bar{x}_{w}}$ (pooied) $=\left[\frac{d f_{1} s_{\bar{x}_{w_{1}}}^{2} d f_{2} s_{\bar{x}_{w_{2}}}^{2}+d f_{3} s_{\bar{x}_{w_{2}}}^{2}}{d f_{1}+d f_{2}+d f_{3}}\right]^{1, n}$

where subscripts $1,2,3$ refer to the various analytical methods, $n_{i}$ is the number of observations in the $i$-th mean with nonzero weight, and $d f_{i}=n_{i}-$ 1.

In three instances, values come only from emission spectroscopy. This method has produced the la:gest amount of data, and the weighted mean of the emission spectroscopy results is between the weighted means reported from the other $(w)$ analytical procedures. In two other cases the weighted means are pooled from two analytical procedures reporting values for an impurity. The weighted means not pooled in these cases are from analytical methods that have apparent biases for these impurity elements in these plutonium metals.

An approximate t-test, where

$$
t=\frac{\bar{x}_{w_{1}}-\bar{x}_{w_{2}}}{\left(s_{\bar{x}_{w_{1}}}^{2}+s_{\bar{x}_{w_{2}}}\right)^{1 / 2}}
$$

is used to check for significant differences at the 0.05 level among any two of the analytical methods. With judgment based on analytical experience, one can arrive at the same conclusion as the t-test in $80^{\circ} ;$ of the cases. Because of the variety of reporting procedures and the rounding and averaging of results, the estimates of precision calculated for this report, while correct for the data as used, are not entirely satisfactory.

In $20 \%$ of the comparisons, the t-test gives a $\mathrm{t}$ value marginally significant at the 0.05 level. The differences, while statistically significant, are not practically significant. In these few cases, analytical judgment indicates that the weighted means of the pertinent analytical methods can be pooled.

\section{SUMMARY AND RECOMMENDATIONS}

Differences beiween the weighted neans for some impurities (Table II mav indicate that hiases exist. If there are such biases, they are not consistent among the several impurities: i.e.. one analytical procedure does not always yield higher results than another. Because the methods are supposed to mersure the same quantity and because there seems to be no consistent bias between methods. the weighted means are powled from the methods, except for those cast's noted.

The values given in Tables 1 and $I I$ should be used with judgment. Where there are apparent differences among weighted means, iurther experimental work is recommended. To resolve these differences, individual laboratories shon:ld use the values of Table Il in a conscientious effort $t o \mathrm{ex}$. amine their analytiral methods, especially where large discrepancies occur between their measurements and the ones reported here. In this way, and with consistent reporting practices, the accumulation of future data will he helpful in determining impurity concentrations in plutonium metals even more accurately than shown here.

\section{ACKNOWLEDGMENTS}

We gratefully acknow!edge the efforts and cooperation of the many people at the participating laboratories who contributed the data discussed in this report. The participating laboraiories are: Atlantic Richfield Hanford Company, Hanford. WA; Savannah River Plant, Aiken. SC; Rocky Flats. Golden, CO; Mound Laboratories. Miamisburg, $\mathrm{OH}$ : Argonne National Laboratory. Chicago. IL; and Los Alamos Scientific Laboratory, Los Alamós, NM.

\section{REFERENCES}

1. C. J. Martell, "The Effect of Particle Size on the Carrier-Distillation Analysis of $\mathrm{PuO}_{2}, "$ Los Alamos Scientific Laboratory report 1.A-F.454 (February 1974).

2. D. F. Andrews, "A Robust Method for Multiple Linear Regression." Technometrics 16. 523-531 (November 1974). 


\section{APPENDIX I}

COMPUTEF PROGRAM USED FOR STATISTICAL EVALUATION OF THE ANALYTICAL DATA

PHOLARM HAIN (INP, OUT)

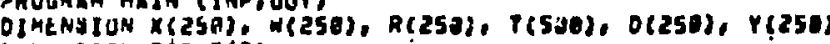

OLHENSION TITLE(S)

At 10 IIILE,DAT

SeO

DO 120 MHal, 00

HEQU i30, (IIILE (K), Mes, 5 )

Jestis

PaIN) 240 ,

Phlit? 15e, (TITLE(K),Kas, 5 )

NCTO

QEAD 168 . N

REAO \$7G, (X)

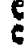

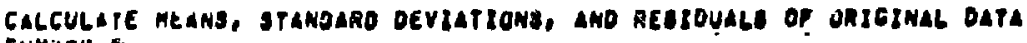

$5 \cup \cos =0.0$

susxay, a

yasion

Yitis.

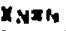

so da iadent

Silqusuaxexcti)

10 CUNTINUE

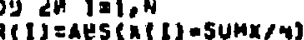

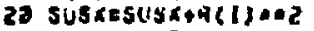

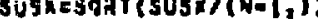

AHB=SUEX $150 \mathrm{~T} T(X N)$

CALL SOHTI (N,EOT,T)

AREMOO (N, Z)

$M X \in N / 2$

NTENX?

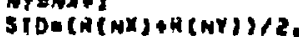

IS (NH,EO, I) STOER(NY)

YMMES IMU:A

PHINT 108, XMK,XAB

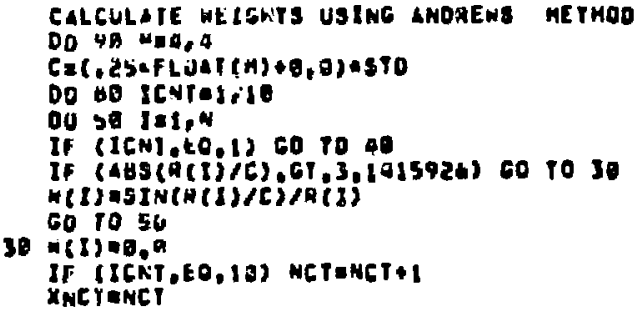




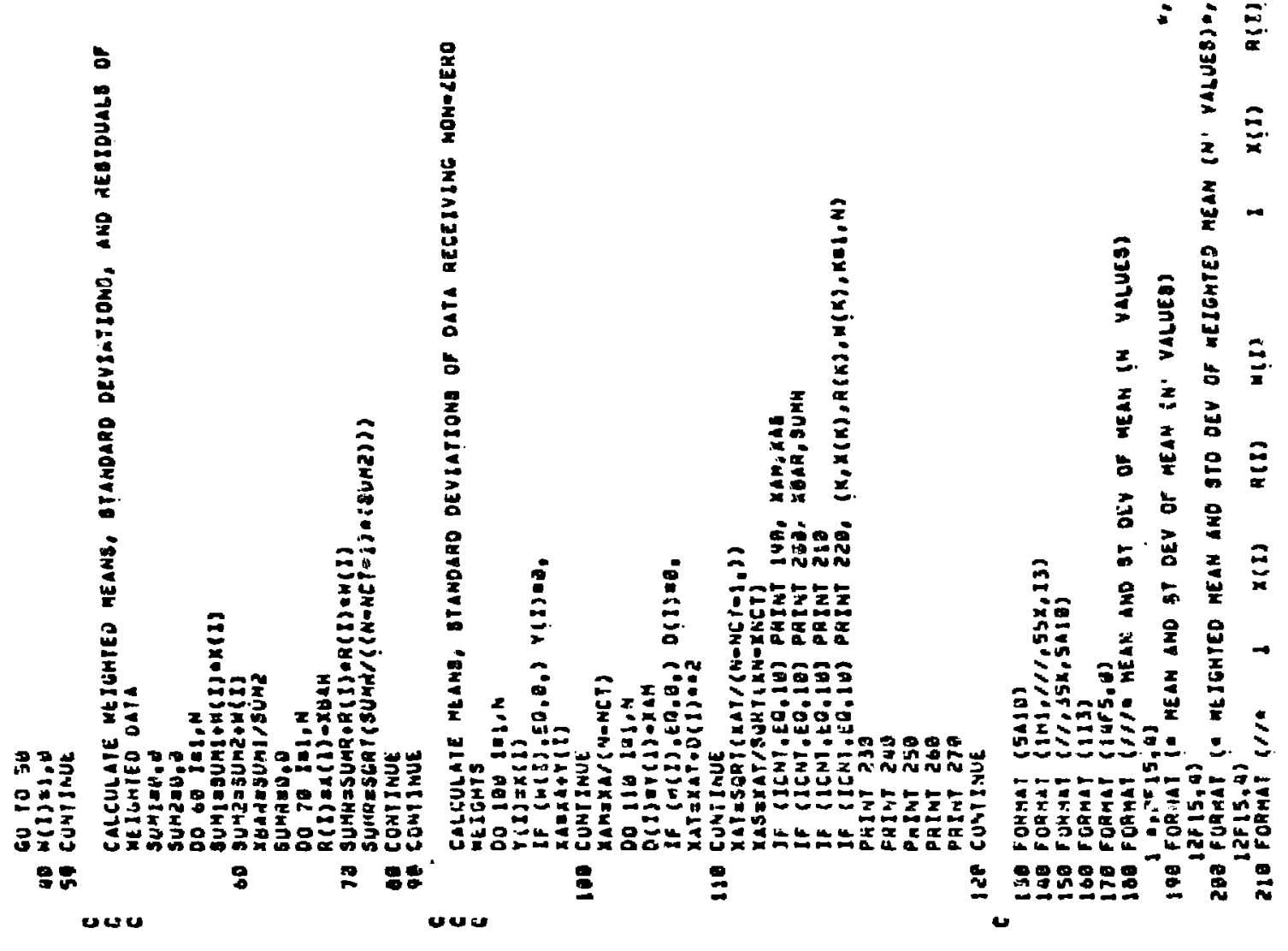




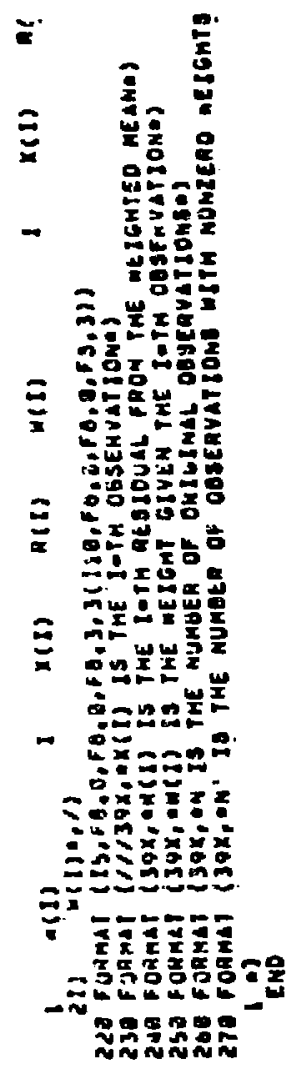




\section{APPENDIX II}

DATA, RESIDUALS, WEIGHTS, AND VARIOUS MEANS AND STANDARD

DEVIATIONS FOR FACH IMPURITY, FLUTONIUM METAL, AND ANALYTICAL PHOCEDURF,

\begin{tabular}{|c|c|c|}
\hline Analytical Method & Impurity & Puge \\
\hline \multirow{2}{*}{\multicolumn{3}{|c|}{$\begin{array}{l}\text { Emission Spectroscopy } \\
\text { Metal H }\end{array}$}} \\
\hline & Al & 9 \\
\hline & $\mathrm{Cr}$ & 10 \\
\hline & $\mathrm{Fe}$ & 11 \\
\hline & $\mathrm{Ni}$ & 12 \\
\hline & $\mathbf{S i}$ & 13 \\
\hline \multirow[t]{5}{*}{ Metal P } & Al & 14 \\
\hline & $\mathrm{Cr}$ & 15 \\
\hline & $\mathrm{Fe}$ & 16 \\
\hline & $\mathrm{Ni}$ & 17 \\
\hline & $\mathbf{S i}$ & 18 \\
\hline \multirow[t]{5}{*}{ Metal R } & Al & 19 \\
\hline & $\mathrm{Cr}$ & 20 \\
\hline & $\mathrm{Fe}$ & 21 \\
\hline & $\mathrm{Ni}$ & 22 \\
\hline & $\mathrm{Si}$ & 23 \\
\hline \multicolumn{3}{|l|}{ Chemical Method } \\
\hline Metal H & $\mathrm{Fe}$ & 24 \\
\hline Metal P & $\mathrm{Fe}$ & 25 \\
\hline Metal R & $\mathrm{Fe}$ & 26 \\
\hline \multicolumn{3}{|l|}{$\begin{array}{l}\text { Spark Source Mass } \\
\text { Spectroscopy }\end{array}$} \\
\hline \multirow[t]{4}{*}{ Metal $\mathrm{H}$} & Al & 27 \\
\hline & $\mathrm{Cr}$ & 28 \\
\hline & $\mathrm{Ni}$ & 29 \\
\hline & Si & 30 \\
\hline \multirow[t]{4}{*}{ Metal P } & A] & 31 \\
\hline & $\mathrm{Cr}$ & 32 \\
\hline & $\mathrm{Ni}$ & 33 \\
\hline & $\mathbf{S i}$ & 34 \\
\hline \multirow[t]{4}{*}{ Metal R } & $\mathrm{Al}$ & 35 \\
\hline & $\mathrm{Cr}$ & 36 \\
\hline & $\mathrm{Ni}$ & 37 \\
\hline & $\mathrm{Si}$ & 38 \\
\hline \multicolumn{3}{|l|}{ Atomic Absorption } \\
\hline Metal H & Al & 39 \\
\hline & $\mathrm{Cr}$ & 40 \\
\hline & $\mathrm{Fe}$ & 41 \\
\hline & $\mathrm{Ni}$ & 42 \\
\hline \multirow[t]{5}{*}{ Metal R } & $\begin{array}{l}\mathrm{Si} \\
\mathrm{Al}\end{array}$ & $\begin{array}{l}43 \\
44\end{array}$ \\
\hline & $\begin{array}{l}\mathrm{AI} \\
\mathrm{Cr}\end{array}$ & 45 \\
\hline & $\mathrm{Fe}$ & 46 \\
\hline & $\mathrm{Ni}$ & 47 \\
\hline & $\mathrm{Si}$ & 48 \\
\hline
\end{tabular}




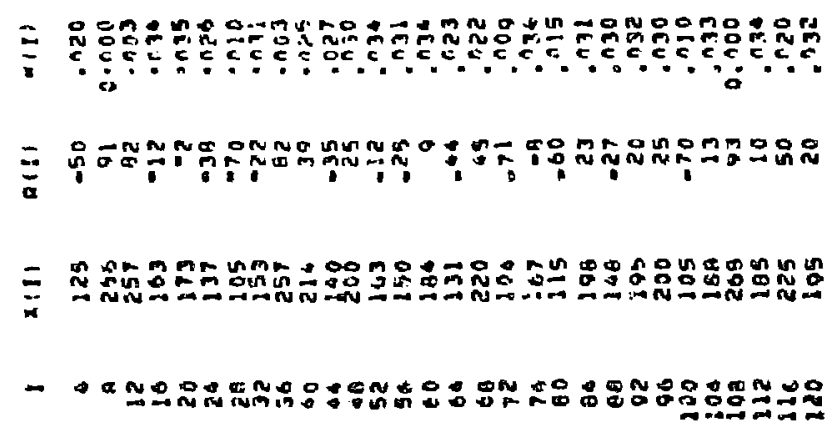

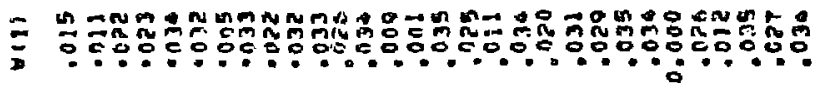

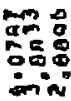

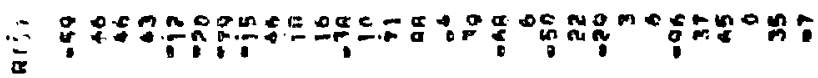

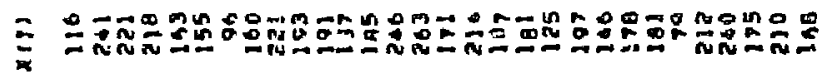

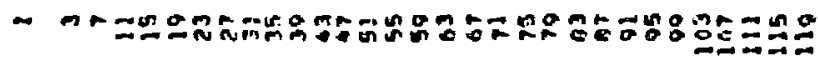

in

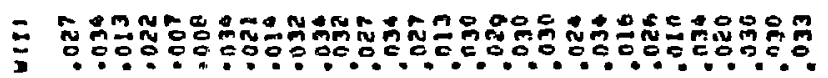

I

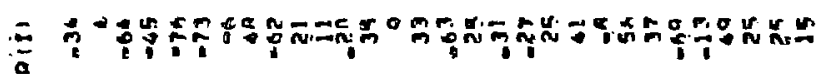

$\frac{\mathbf{z}}{\mathbf{z}}$

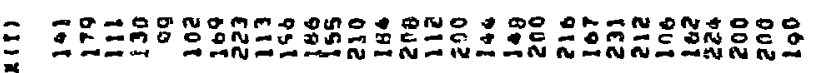

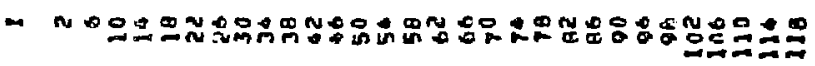

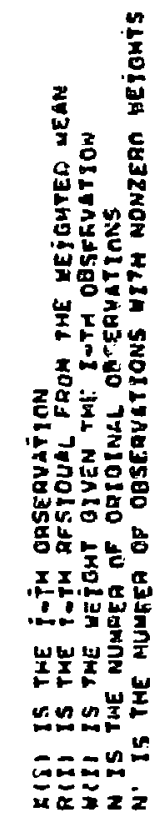

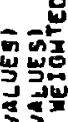

$z z^{4}$

$2 z^{4}$

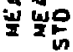

t。

㟧

这结

क जि

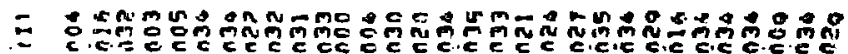

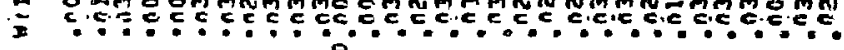

三

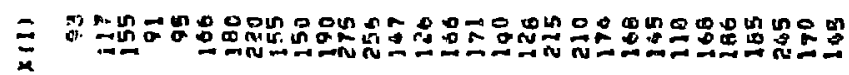

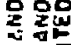

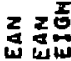

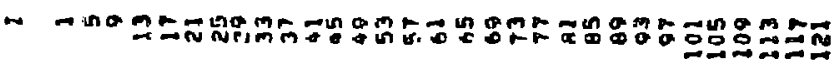




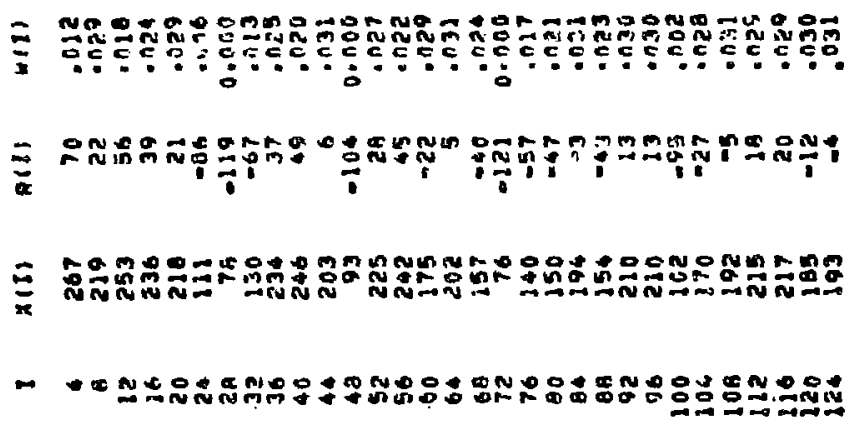

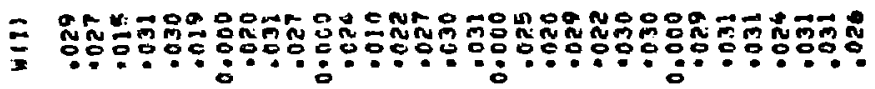

$\therefore$ =

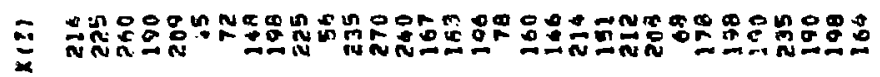

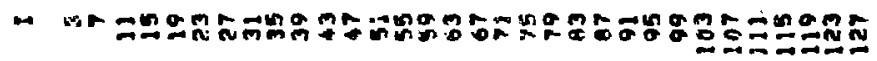

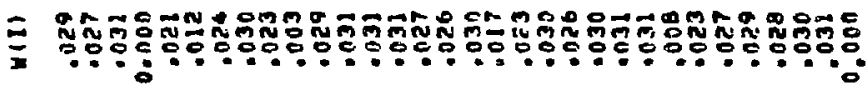

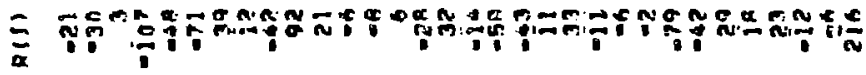

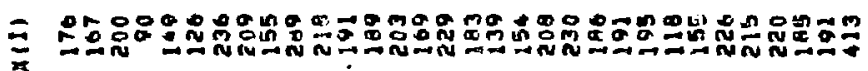

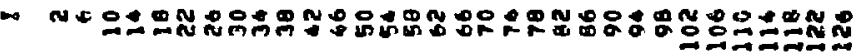

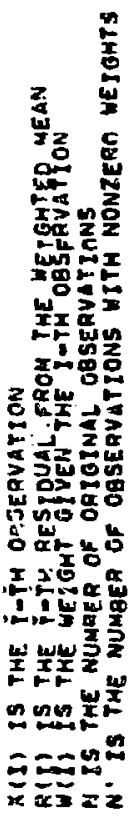

三

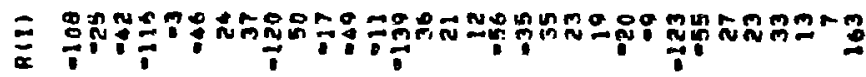

녕?

喽娄

三

울울은 
MEAN ANO ST OEV OF MEAN IN VALUES! MEAN ANO ST DEY OF WEAN (N' VALUES) $\begin{array}{ll}949.5982 & 18.9313 \\ 965.466 & 10 \% 932 \\ 962.8054 & 1090942\end{array}$

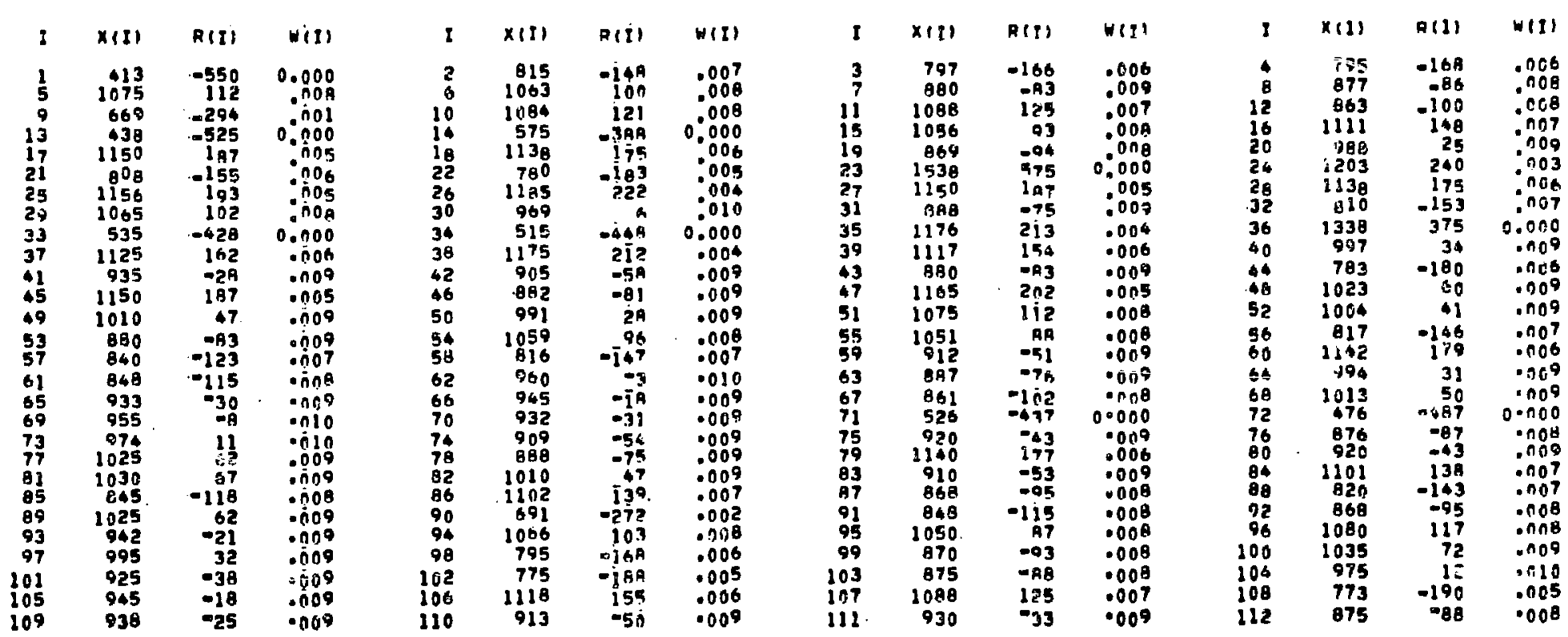

$x(1)$ IS THE İoTh OBSERVATION

RiII IS THE F-TH RESIDUAL FROM THE WEjGHTEO MEAN

WII IS THE WEIGHT GIVEM THE I-TK OQSFRVATION

$N$ IS TME MUMAER OF. ORIGINAL OBSERVATINNS

$N$ ' IS THE NUMBEP OF OBSERVATIONS WITH NONZERO WEIGHTS 


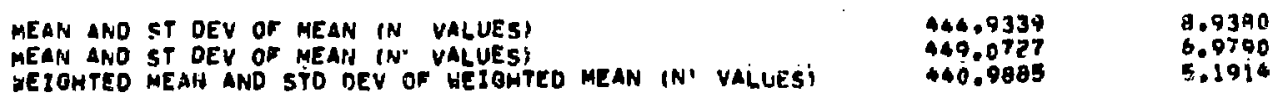

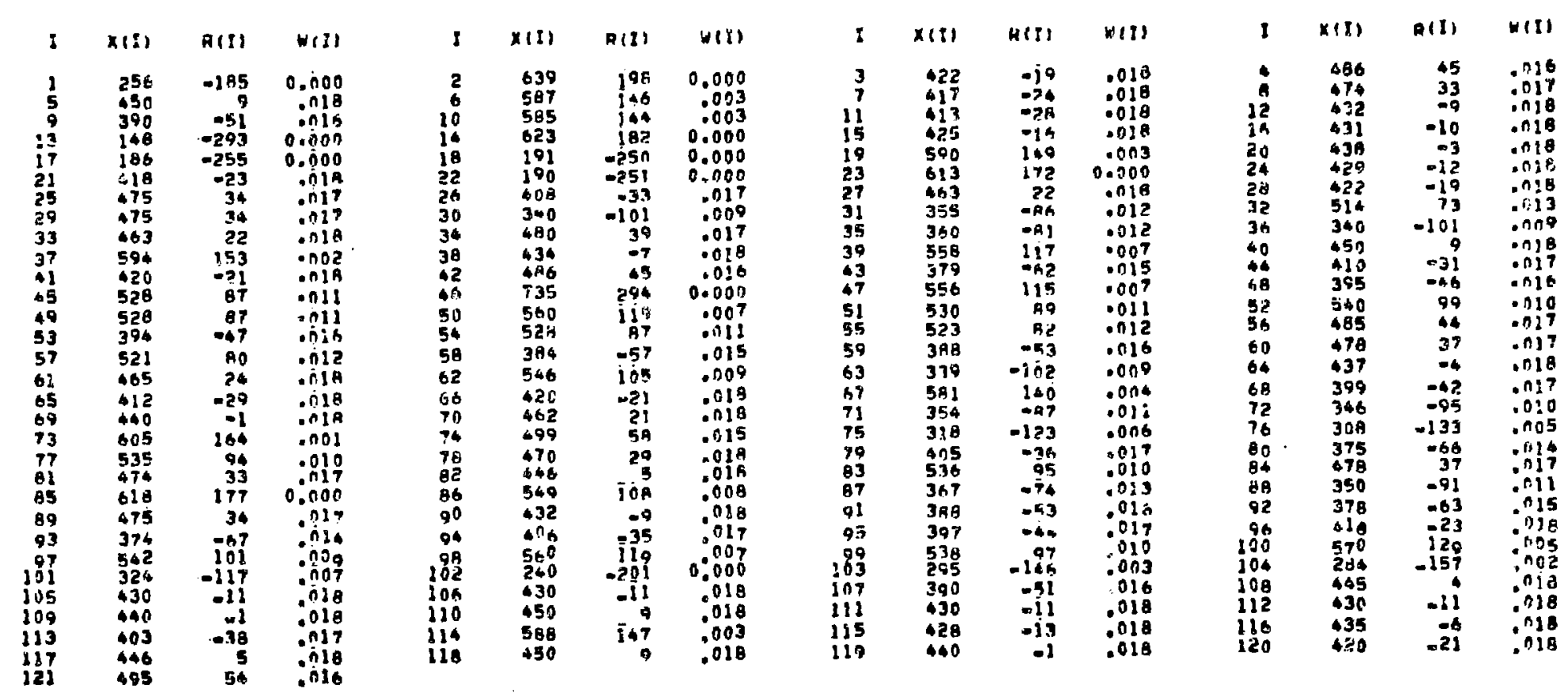

AII) IS THE T-TH OASERVATION

R(i), IS THE GOTH RESTOUAL FROM THE WEjGHTEO MEAN

WI) IS THE UEIGHT GIVEN THE I-TH OBSERVATION

$N_{1}$ IS THE NUMBEA OF OBSERVATIONS WITH NOHZERO WEIGHTS 


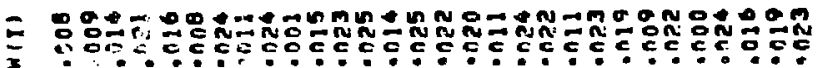

こ

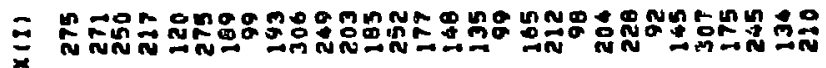

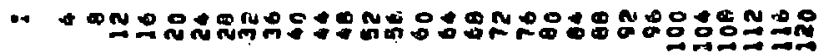

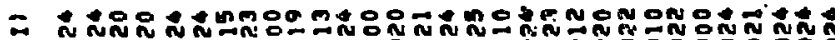

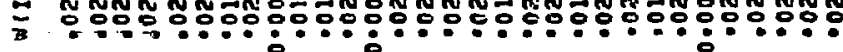

웅용

ํㅜㅇㅇㅡ.

inim

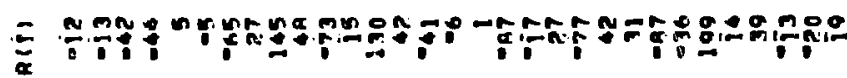

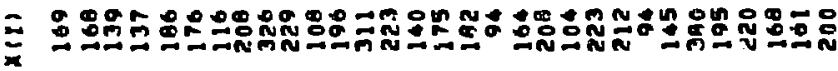

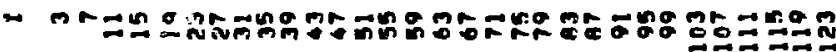

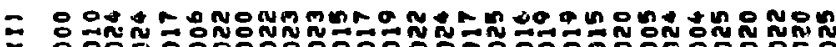

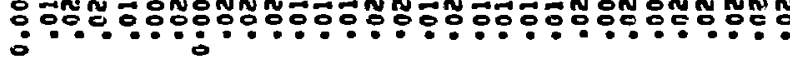

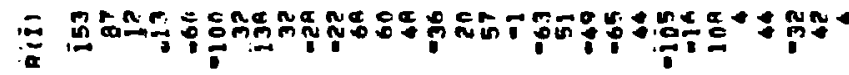

E

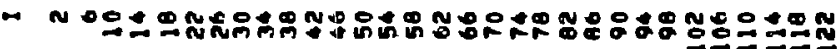

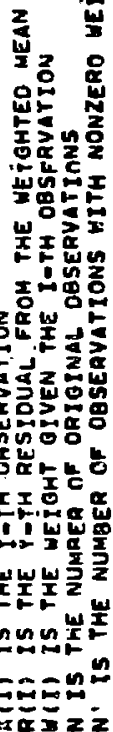

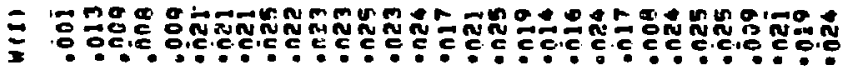

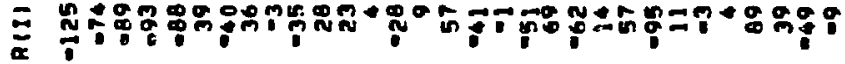

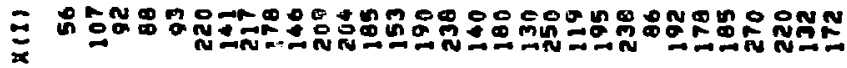

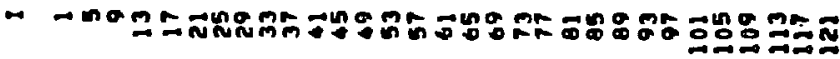


aLUMINUH METAL P EMISSION

MEAN ANO ST DEY OF MEAN IN YALUES) MEAN AND ST DEY OF MEAN IN' VALLESI

\section{$55.3069 \quad 1.7458$}

$\begin{array}{ll}55.1563 & 1.5306 \\ 55.4605 & 1.2720\end{array}$

$\begin{array}{rr}1 & x(1) \\ 2 & 65 \\ 6 & 81 \\ 10 & 67 \\ 14 & 75 \\ 18 & 9 \\ 22 & 54 \\ 26 & 62 \\ 30 & 54 \\ 34 & 63 \\ 38 & 6 \\ 42 & 5 \\ 46 & \\ 50 & 33 \\ 54 & 73 \\ 58 & 67 \\ 62 & 35 \\ 66 & 70 \\ 70 & 38 \\ 74 & 70 \\ 78 & 62 \\ 82 & 20 \\ 86 & 35 \\ 90 & 69 \\ 96 & 61 \\ 98 & 40\end{array}$

(13) 15 THE I-TH OASERYRTION

R(1) IS THE IOTH RESTOUAL FROM THE WE TGRYED MEAN (II) IS THE UEIGHT GIYEN FHE I-TH OBSERVATION

IS. THE NJMAER OF ORIGINAL OBSERYATIONS

$N$. IS THE NUMAER OF OBSERVATIONS WITH NONZERS WE TGHTS
(II) A13) WiI)

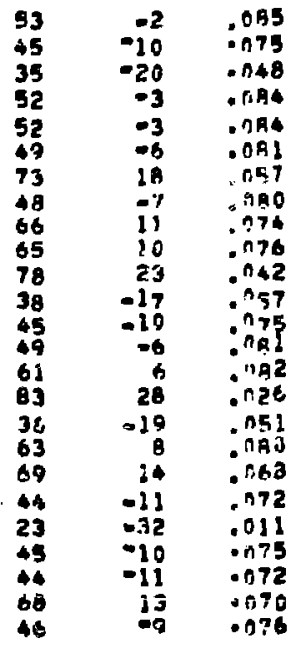


Chromiun meidL P EMISSION

MEAN AND ST DEV OF MEAN IN. VALUESI

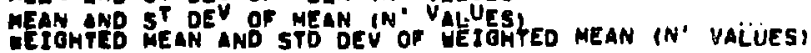

\section{$48.7526 \quad 2.1189$}

$\begin{array}{rr}47.9655 & 1.0894 \\ 48.5306 & .9064\end{array}$

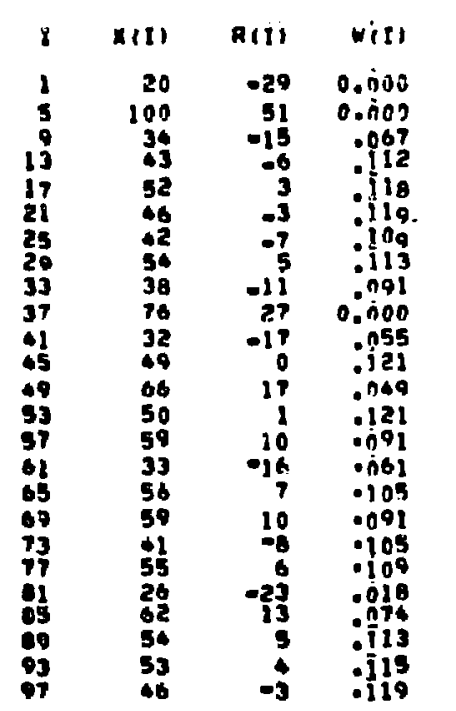

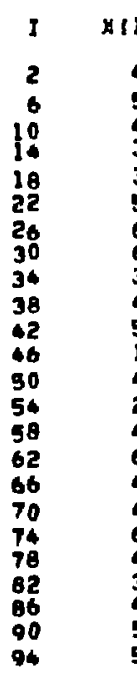

Bij) N(I)

42
56
49
39

32

51

60
63
39
45

54

14
45

$\because 0$ BO

.121

Xit) IS THE IATH OBSERVATION

R(1) IS THE T-TH AESTOUAL FROM THE WEFOHPEO MEAN

(II) PS THE HEIOHT GIVEN THE OFFH OASTAVATION

N. IS THE MUMBER OF OBSERVATIONS WITH NONZERO WEIOHTS 


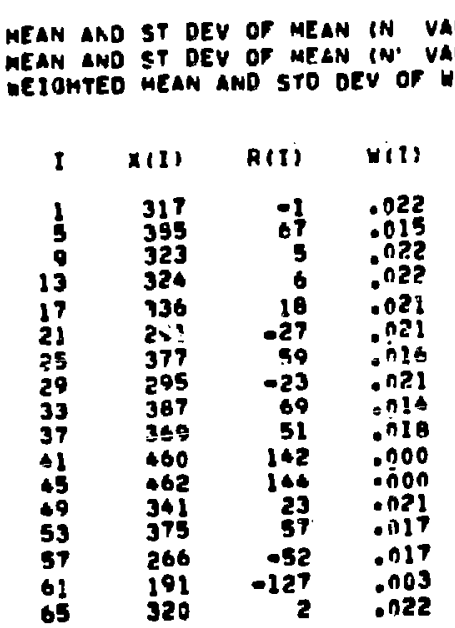

\section{$323.1791 \quad 7.7823$ \\ $\begin{array}{ll}323.1791 & 7.7923 \\ 370.1077 & 5.4802\end{array}$}

\begin{tabular}{|c|c|c|c|c|c|c|c|}
\hline I & $x(I)$ & Ri(i) & $\forall(1)$ & $I$ & $x(1)$ & $R(T)$ & $w(I)$ \\
\hline $\begin{array}{r}2 \\
6 \\
10 \\
14\end{array}$ & $\begin{array}{l}325 \\
393 \\
303 \\
6118\end{array}$ & $\begin{array}{r}7 \\
75 \\
-15 \\
91\end{array}$ & $\begin{array}{l}.022 \\
.013 \\
0021 \\
010\end{array}$ & $\begin{array}{l}3 \\
11 \\
15\end{array}$ & $\begin{array}{l}306 \\
386 \\
425 \\
175\end{array}$ & $\begin{array}{r}-12 \\
68 \\
\ln 7 \\
=\ln 43\end{array}$ & $\begin{array}{l}.022 \\
.015 \\
.007 \\
.000\end{array}$ \\
\hline $\begin{array}{l}10 \\
22 \\
26 \\
30 \\
30 \\
38 \\
42 \\
46 \\
54\end{array}$ & $\begin{array}{l}285 \\
317 \\
274 \\
348 \\
219 \\
263 \\
353 \\
340 \\
414 \\
312\end{array}$ & $\begin{array}{r}-33 \\
-1 \\
-44 \\
7 n \\
-99 \\
-55 \\
35 \\
-19 \\
94 \\
-4\end{array}$ & $\begin{array}{l}.020 \\
.022 \\
.019 \\
.015 \\
.008 \\
.017 \\
.020 \\
.021 \\
.009 \\
.022\end{array}$ & $\begin{array}{l}19 \\
23 \\
27 \\
31 \\
35 \\
39 \\
43 \\
47 \\
51 \\
55\end{array}$ & $\begin{array}{l}335 \\
276 \\
289 \\
227 \\
397 \\
302 \\
295 \\
383 \\
292 \\
45 ?\end{array}$ & $\begin{array}{r}17 \\
-42 \\
-29 \\
-91 \\
-39 \\
-16 \\
-33 \\
29 \\
-27 \\
134\end{array}$ & $\begin{array}{l}.021 \\
.019 \\
.020 \\
.010 \\
.1119 \\
.021 \\
.020 \\
.015 \\
.021 \\
.002\end{array}$ \\
\hline $\begin{array}{l}58 \\
62\end{array}$ & $\begin{array}{l}236 \\
245 \\
270\end{array}$ & $\begin{array}{l}-84 \\
-73 \\
-4 A\end{array}$ & $\begin{array}{l}.011 \\
014 \\
10\end{array}$ & $\begin{array}{l}59 \\
63 \\
67\end{array}$ & $\begin{array}{l}328 \\
258 \\
309\end{array}$ & $\begin{array}{r}10 \\
-6 n \\
-9\end{array}$ & $\begin{array}{l}.022 \\
.016 \\
.022\end{array}$ \\
\hline
\end{tabular}

$\begin{array}{rrrr}I & \times(1) & 0(1) & w(1) \\ & 281 & -37 & .020 \\ 8 & 350 & 32 & .020 \\ 12 & 354 & 36 & .020 \\ 16 & 308 & -10 & .022 \\ 20 & 326 & 0 & .022 \\ 24 & 372 & 54 & .017 \\ 28 & 263 & -55 & .017 \\ 32 & 328 & 19 & .072 \\ 36 & 270 & -48 & .018 \\ 40 & 456 & 138 & .001 \\ 66 & 310 & -08 & .022 \\ 68 & 231 & -87 & .111 \\ 58 & 327 & 9 & .022 \\ 56 & 236 & -82 & .012 \\ 60 & 366 & 48 & .018 \\ 64 & 341 & 23 & .021\end{array}$

$x(1)$ IS THE I-jM OASERYATION

Ril IS THE T-FH, AESIOUAL FROM THE WETGMTEO MEAR!

WII TS THE WE OHT OIVEN THE I-TH OBSFAVATION

N IS THE NUMOEF OF ORIOINAL OBSERVATINNS

N IS THE NUMAER NF ORTGINAL OBSER WITH NONZERO WEIGHTS 
NICKEL METAL D EMISSTON

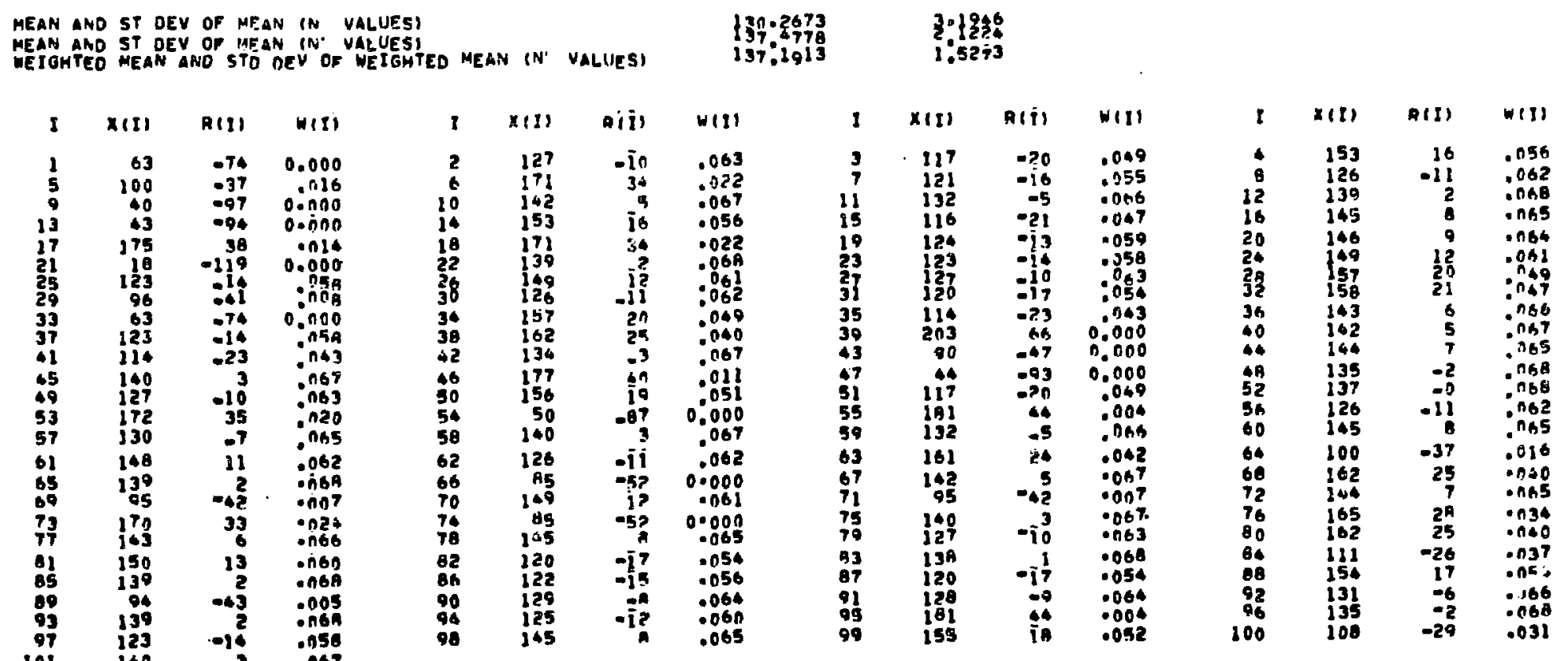

XIII IS THE IOTH OQSERYATION

R(I) IS THE I-TH RESIPUAL FROM THE WETgHTEO MEAN

$N$ is THE NUMAER of ORTOTNIS OBSERVATIOHS

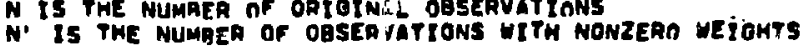




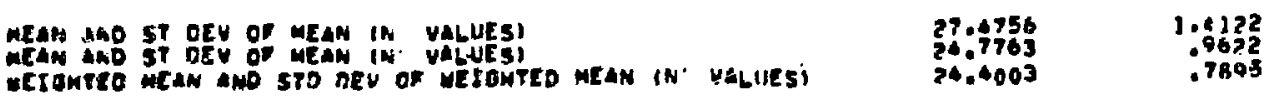

\begin{tabular}{|c|c|c|c|c|c|c|c|c|c|c|c|c|c|c|c|}
\hline 1 & $x+21$ & ค(1) & जits & $t$ & $x \leq 81$ & aiti & $H(I)$ & $I$ & $x(s)$ & a(i) & WII & 2 & $x( \pm)$ & $\theta(1)$ & $w(1)$ \\
\hline 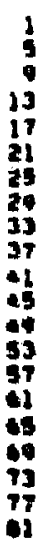 & $\begin{array}{l}27 \\
31 \\
15 \\
24 \\
18 \\
10 \\
12 \\
31 \\
22 \\
18 \\
17 \\
63 \\
24 \\
28 \\
31 \\
21 \\
15 \\
18 \\
37 \\
29 \\
17\end{array}$ & $\begin{array}{r}3 \\
-7 \\
-9 \\
-9 \\
-14 \\
-12 \\
-13 \\
-2 \\
-1 \\
-7 \\
39 \\
2 \\
7 \\
-9 \\
-10 \\
13 \\
1 \\
-7\end{array}$ & 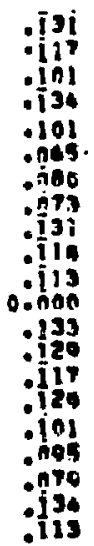 & $\begin{array}{l}2 \\
6 \\
10 \\
14 \\
10 \\
22 \\
26 \\
30 \\
34 \\
30 \\
42 \\
46 \\
30 \\
96 \\
50 \\
62 \\
66 \\
70 \\
70 \\
78 \\
12\end{array}$ & $\begin{array}{l}15 \\
23 \\
39 \\
5 \\
26 \\
33 \\
39 \\
29 \\
23 \\
23 \\
27 \\
26 \\
37 \\
22 \\
27 \\
23 \\
59 \\
20 \\
10 \\
24 \\
26\end{array}$ & 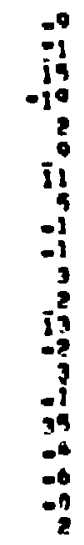 & 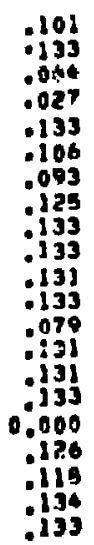 & $\begin{array}{l}3 \\
7 \\
11 \\
15 \\
19 \\
23 \\
27 \\
31 \\
35 \\
39 \\
43 \\
47 \\
51 \\
55 \\
59 \\
63 \\
67 \\
71 \\
75 \\
79\end{array}$ & $\begin{array}{l}27 \\
22 \\
24 \\
30 \\
20 \\
16 \\
21 \\
9 \\
20 \\
13 \\
35 \\
38 \\
66 \\
17 \\
20 \\
50 \\
18 \\
43 \\
24 \\
46\end{array}$ & $\begin{array}{r}3 \\
-2 \\
-0 \\
6 \\
-4 \\
-2 \\
-3 \\
-15 \\
-15 \\
-11 \\
11 \\
10 \\
-2 \\
-7 \\
-12 \\
-4 \\
10 \\
-0 \\
-0 \\
20\end{array}$ & $\begin{array}{l}.131 \\
1131 \\
.134 \\
1122 \\
.126 \\
.107 \\
.129 \\
.059 \\
1126 \\
.086 \\
.093 \\
.071 \\
0.000 \\
.113 \\
.126 \\
0.000 \\
.116 \\
.033 \\
.134 . \\
.025\end{array}$ & $\begin{array}{l}1 \\
12 \\
12 \\
36 \\
20 \\
24 \\
28 \\
38 \\
36 \\
46 \\
46 \\
46 \\
32 \\
36 \\
60 \\
64 \\
68 \\
72 \\
76 \\
80\end{array}$ & $\begin{array}{l}50 \\
35 \\
20 \\
30 \\
31 \\
20 \\
20 \\
40 \\
26 \\
27 \\
37 \\
41 \\
30 \\
31 \\
31 \\
26 \\
31 \\
26 \\
76 \\
20\end{array}$ & $\begin{array}{r}28 \\
11 \\
-6 \\
-6 \\
7 \\
-4 \\
16 \\
16 \\
2 \\
3 \\
13 \\
17 \\
6 \\
7 \\
7 \\
2 \\
7 \\
2 \\
52 \\
-4\end{array}$ & 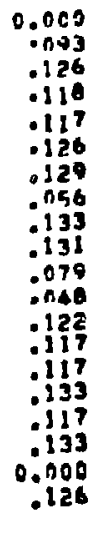 \\
\hline
\end{tabular}

XIII) IS PHE I-FM OASERVATION

V(I) IS TME UEYOHT GIVEN THE I-PH OBSEAVLTION

* IS TME NUMAES OF ODIOTMAL OBSERVATI ANS

N. IS TME NUMAE OO OgSERYATIONS MITH NOMZEAO MEFOHTS 


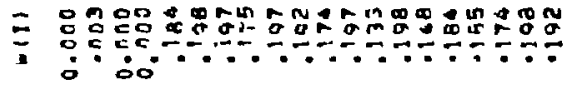

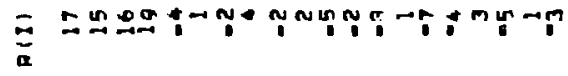

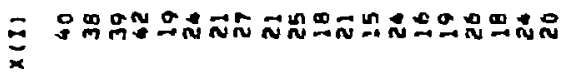

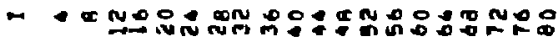

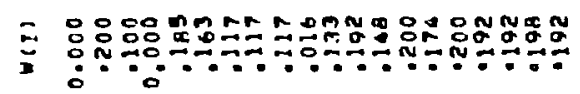

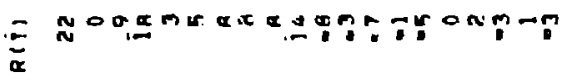

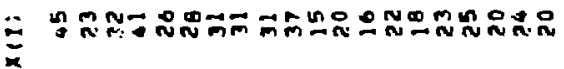

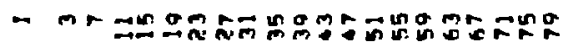

象

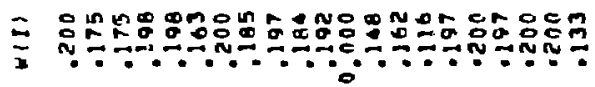

$=7++-\infty$ mem

Б

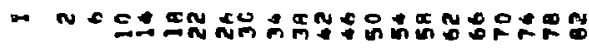

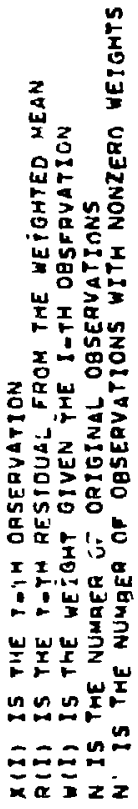

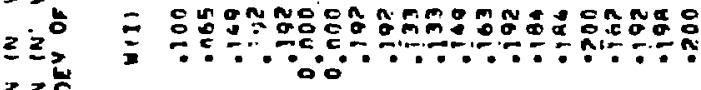

$\geq \geq$

두을

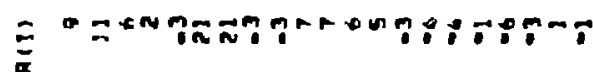

岁常:

战竞

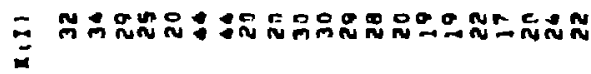

올울요

M - MOM 
WEAM ARO ST OEV OP MEAN IN VALUES!

DEJOHTED MESN AND STD DEV OF WEIGHTEO MEAN IN VALIUESI

\section{$\begin{array}{lr}44.5057 & 1.75 n 6 \\ 44,8415 & 1.0425 \\ 45,0046 & .08 n 6\end{array}$}

\begin{tabular}{|c|c|}
\hline A (1) & $w(3)$ \\
\hline 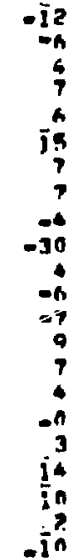 & 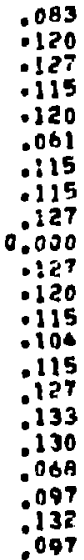 \\
\hline
\end{tabular}

$\begin{array}{cc}1 & \times 111 \\ 3 & 52 \\ 7 & 56 \\ 11 & 30 \\ 15 & 34 \\ 19 & 40 \\ 73 & 39 \\ 27 & 36 \\ 31 & 51 \\ 35 & 34 \\ 39 & 36 \\ 43 & 30 \\ 47 & 58 \\ 51 & 38 \\ 55 & 36 \\ 59 & 56 \\ 63 & 36 \\ 67 & 36 \\ 71 & 50 \\ 75 & 40 \\ 79 & 50 \\ 63 & 38 \\ 87 & 15\end{array}$

R(i)

11
11

$\begin{array}{rr}11 & 0109 \\ -15 & 061\end{array}$

$-11 \quad 060$

.124

$\because 120$

$6 \quad .120$

$-11 \quad .090$

$-\frac{1}{1}$

$-\frac{1}{13}$

Obl

- 076

115

ins

il .000

$-i 1$ i

.124

.126

.124

0.000

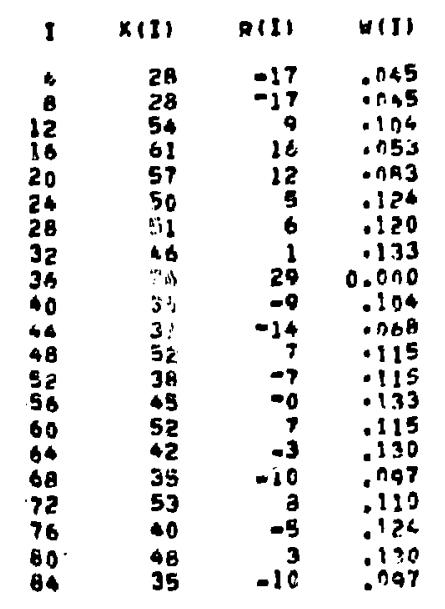

X13i IS THE i-tM ORSCaVation

R(I) IS THE F TH RFSTOULL EROM THE WE IOHTED MEAN

HiII IS PHE WEIOHT GIVEN THE I-TH OQSFRYTION

$N$ IS THE NUMAER OF ORIOLNAL OBSERYATIONAS

N' IS THE NUMAER OF ORIOTNA OBSEA WITH NONZER', WEIGHTS 


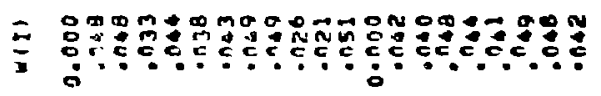

$$
\begin{aligned}
& \text { Б }
\end{aligned}
$$

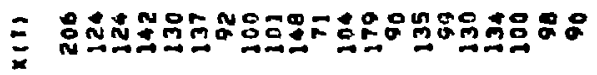

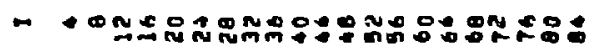

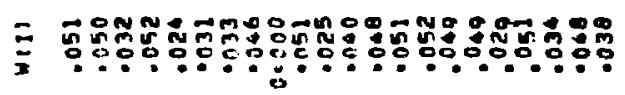

So:

宓品

$\rightarrow \infty$

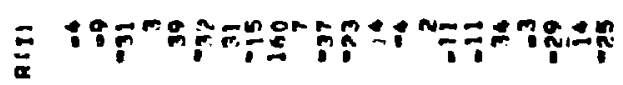

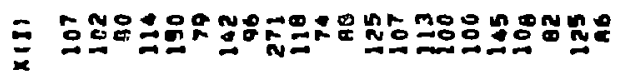

-

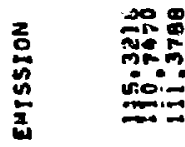

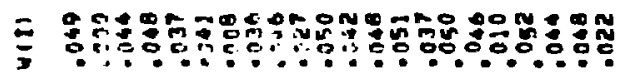

×

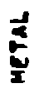

Е

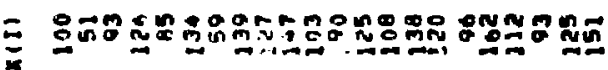

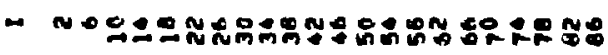

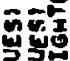
Sị 5 5. $\geq z$ $z \geq 0$ 분 능을 3 屴岩z $55 \frac{10}{2}$ 웆운 $\geq \geq 0$

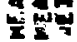

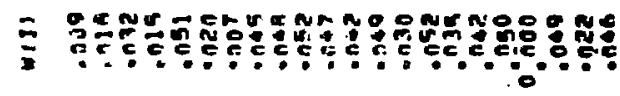
そ

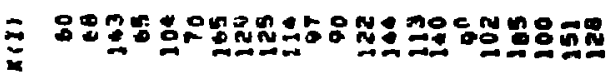

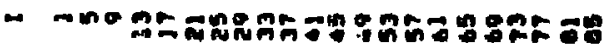

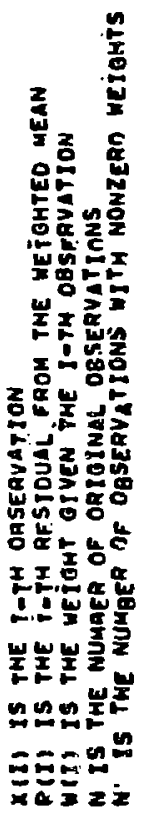


MEAN ROM ST DEV OF MEAN (N VALUESI

MEAN TND ST DEY OF MEAN $N$ N

WEIOHTED MEAN ANO STO DEV OF UEIOHTED MEAN (N' VALUES)

$\begin{array}{rr}97.5253 & 1.6758 \\ 99.1995 & 1.5276 \\ 101.3036 & 1.16 \% 90\end{array}$

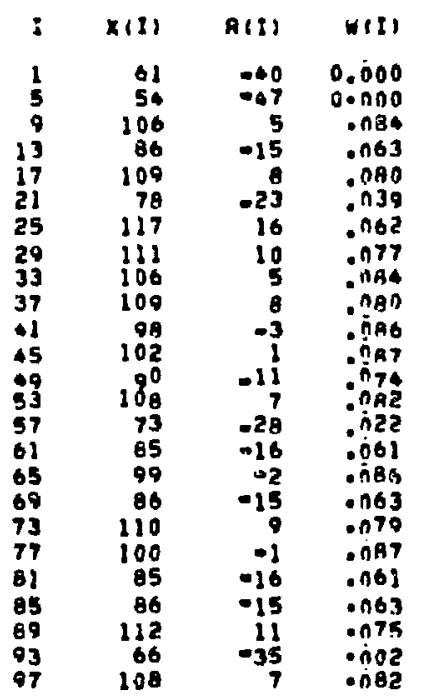

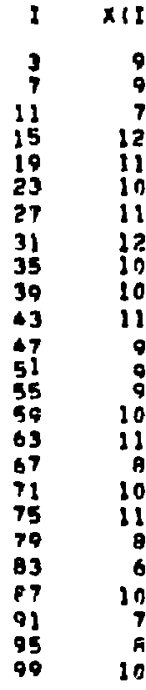

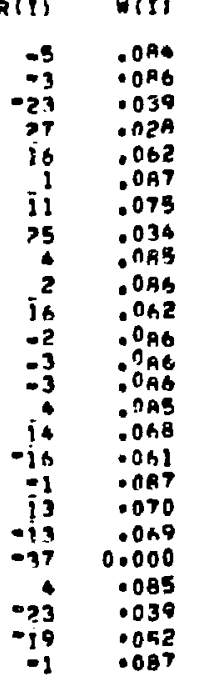

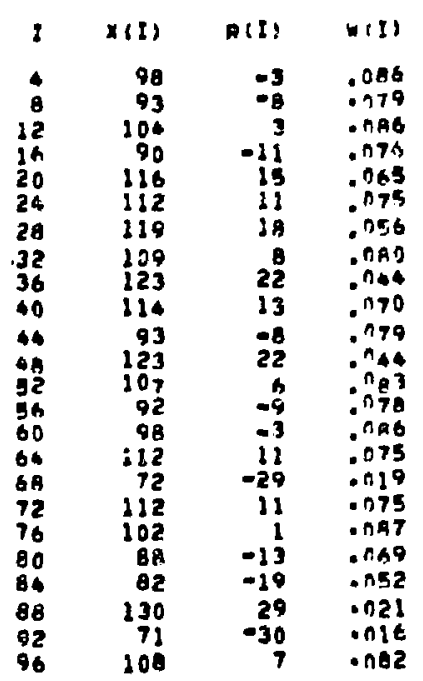

$x(i)$ IS THE I-TH ORSERYATION

RiI, IS THE I-TH OASEQVATION (11) IS THE WEIGNT GIVEN TKE I-TH OBSFRVATION

W IS THE NUMAER OF ORIGINAL OBSERVATIONS

$N$ IS THE NUMBER OF OBSEAVATIONS WITH NONZERO WETOHTS 
hean ANO ST OEV OP MEAN IN VALUES) MEAN AND ST DEV OF MEAN IN' VGLUEST METEO MEAN (N VALIJESI

$\begin{array}{ll}35.8736 & 1.2675 \\ 34.7262 & : 178 \\ 34.0070 & .9626\end{array}$

\begin{tabular}{|c|c|c|c|c|c|c|c|c|c|c|c|c|c|c|c|}
\hline I & $x(1)$ & $R(I)$ & a $(x)$ & I & A(I) & P(1) & $6(8)$ & 1 & $x(I)$ & R(T) & $\forall(I)$ & 1 & 265 & a $(1)$ & $(1)$ \\
\hline $\begin{array}{l}1 \\
5\end{array}$ & $\begin{array}{r}43 \\
46\end{array}$ & $\begin{array}{l}8 \\
9\end{array}$ & $\begin{array}{l}.09 \% \\
.073\end{array}$ & $\begin{array}{l}2 \\
6\end{array}$ & $\begin{array}{l}23 \\
78\end{array}$ & $\begin{array}{l}-9 \\
-7\end{array}$ & $\begin{array}{l}.096 \\
.103\end{array}$ & $\begin{array}{l}3 \\
?\end{array}$ & $\begin{array}{l}3 A \\
40\end{array}$ & $\begin{array}{l}3 \\
5\end{array}$ & $\begin{array}{l}120 \\
1100\end{array}$ & 4 & $\begin{array}{l}28 \\
03\end{array}$ & $\begin{array}{r}-7 \\
B\end{array}$ & $\begin{array}{l}103 \\
0 \pi 51\end{array}$ \\
\hline 9 & 39 & 1 & $.10 A$ & 10 & 36 & 1 & 112 & 11 & 38 & 3 & .117 & 12 & 28 & 11 & . nst \\
\hline 13 & $\begin{array}{l}28 \\
53\end{array}$ & $\vec{P}$ & $\begin{array}{l}\because n 3 \\
\because n \& A\end{array}$ & 14 & 64 & -37 & $\begin{array}{l}0 . n 00 \\
\cdot \eta \theta a\end{array}$ & $\begin{array}{l}15 \\
19\end{array}$ & $\begin{array}{l}28 \\
45\end{array}$ & $\begin{array}{l}-7 \\
10\end{array}$ & $\begin{array}{l}103 \\
.089\end{array}$ & $\begin{array}{l}16 \\
20\end{array}$ & $\begin{array}{l}33 \\
30\end{array}$ & $\begin{array}{l}-2 \\
-5\end{array}$ & $\begin{array}{l}112 \\
.1126\end{array}$ \\
\hline 21 & 25 & -9 & - 195. & है? & 48 & -11 & .069 & 23 & 36 & 1 & & 24 & 35 & 0 & .113 \\
\hline $\begin{array}{l}25 \\
29\end{array}$ & $\begin{array}{l}32 \\
50\end{array}$ & $\begin{array}{l}-3 \\
15\end{array}$ & $\begin{array}{l}111 \\
.044\end{array}$ & $\begin{array}{l}2 h \\
30\end{array}$ & $\begin{array}{l}21 \\
36\end{array}$ & - It & 0173 & 27 & 49 & 16 & $\begin{array}{l}0489 \\
0111\end{array}$ & $\begin{array}{l}2 A \\
32\end{array}$ & 43 & $\begin{array}{l}5 \\
6\end{array}$ & $\begin{array}{l}\ln 108 \\
. \ln 3\end{array}$ \\
\hline 33 & 20 & -15 & - ABA & 34 & 55 & 2n & $\begin{array}{l}.112 \\
.037\end{array}$ & $\begin{array}{l}31 \\
35\end{array}$ & 32 & -2 & .112 & 36 & $2 ?$ & 013 & .078 \\
\hline 37 & $4 \theta$ & 13 &.$n 75$ & 38 & $\begin{array}{l}20 \\
28\end{array}$ & -15 & OAB & 39 & 28 & -9 & $\begin{array}{r}.196 \\
.099\end{array}$ & $\begin{array}{l}40 \\
64\end{array}$ & $\begin{array}{l}46 \\
22\end{array}$ & $\begin{array}{r}7 \\
-13\end{array}$ & $\begin{array}{l}.023 \\
.078\end{array}$ \\
\hline 41 & 30 & -1 & .113 & $\begin{array}{l}42 \\
46\end{array}$ & 37 & $\begin{array}{r}-7 \\
2\end{array}$ & $\begin{array}{l}.103 \\
1111\end{array}$ & $\begin{array}{l}43 \\
47\end{array}$ & 39 & 4 & .097 & $A A$ & 38 & i & .112 \\
\hline 69 & 21 & -14 & $\therefore 73$ & 50 & 22 & -13 & -1798 & $5 !$ & 38 & 3 & 110 & 52 & 37 & ${ }_{-7}^{2}$ & $\begin{array}{l}111 \\
: 096\end{array}$ \\
\hline $\begin{array}{l}53 \\
57\end{array}$ & $\begin{array}{l}22 \\
33\end{array}$ & $\begin{array}{r}-13 \\
-2\end{array}$ & $\begin{array}{l}-17 A \\
-112\end{array}$ & $\begin{array}{l}54 \\
53\end{array}$ & $\begin{array}{l}25 \\
43\end{array}$ & -10 & $\begin{array}{l}: 072 \\
.097\end{array}$ & $\begin{array}{l}55 \\
50\end{array}$ & $\begin{array}{l}30 \\
50\end{array}$ & $i^{1} \frac{1}{9}$ & :132 & $\begin{array}{l}56 \\
60\end{array}$ & 40 & 9 & $.0,93$ \\
\hline 61 & 33 & -2 & 0912 & b2 & 39 & 4 & .101 & 63 & 22 & -13 & .073 & 66 & 21 & 91 & .073 \\
\hline 65 & 25 & -10 & .192 & 66 & 26 & -11 & $\begin{array}{r}-0 \text {-日 } \\
0.00\end{array}$ & $\begin{array}{l}67 \\
71\end{array}$ & $\begin{array}{l}72 \\
48\end{array}$ & $\begin{array}{l}37 \\
13\end{array}$ & 0.000 & is & $\begin{array}{l}50 \\
45\end{array}$ & 15 & $\begin{array}{l}=\text { ORA } \\
\text { OARA }\end{array}$ \\
\hline $\begin{array}{l}69 \\
79\end{array}$ & $\begin{array}{l}50 \\
40\end{array}$ & $\begin{array}{r}15 \\
5\end{array}$ & $=064$ & $\begin{array}{l}70 \\
76\end{array}$ & $\begin{array}{l}64 \\
35\end{array}$ & 29 & $\begin{array}{r}0.000 \\
.123\end{array}$ & 75 & 48 & $\begin{array}{l}13 \\
13\end{array}$ & $\begin{array}{l}=075 \\
=079\end{array}$ & 76 & $\$ 0$ & 5 & 10s \\
\hline 77 & 36 & $\underline{\underline{2}}$ & -112 & 78 & 35 & i & .113 & 79 & $3_{8}^{10}$ & -17 & .059 & $\begin{array}{l}80 \\
94\end{array}$ & $\begin{array}{l}20 \\
26\end{array}$ & $\begin{array}{r}-15 \\
-9\end{array}$ & $\begin{array}{l}.038 \\
.008\end{array}$ \\
\hline $\begin{array}{l}81 \\
85\end{array}$ & $\begin{array}{l}16 \\
66\end{array}$ & $\begin{array}{r}017 \\
12\end{array}$ & $\begin{array}{r}-058 \\
.086\end{array}$ & $\begin{array}{l}82 \\
86\end{array}$ & $\begin{array}{l}12 \\
26\end{array}$ & $\begin{array}{r}-23 \\
-9\end{array}$ & $\begin{array}{r}.025 \\
.096\end{array}$ & 87 & 57 & 22 & $\begin{array}{l}110 \\
.026\end{array}$ & & & & \\
\hline
\end{tabular}

(II) IS THE P-TH OASEAVATION

R(I) IS THE T-TH RFSPOUAL FROM THE WEPOHTEO MEAN

W(I) IS THE WEIAHT OIVEN THE I-TH OSSFRVATION

$N$ IS THE NUMRER OF ORIGINAL OBSERVATIANS

$N$. IS THE NUMAER DF OQSERVATIONS WITH NGNZERO HETGHTS 


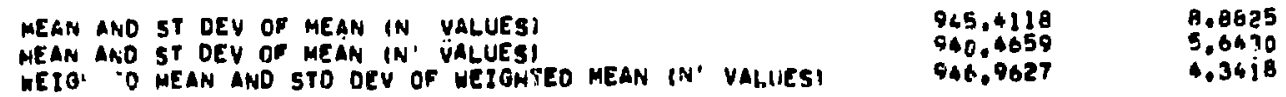

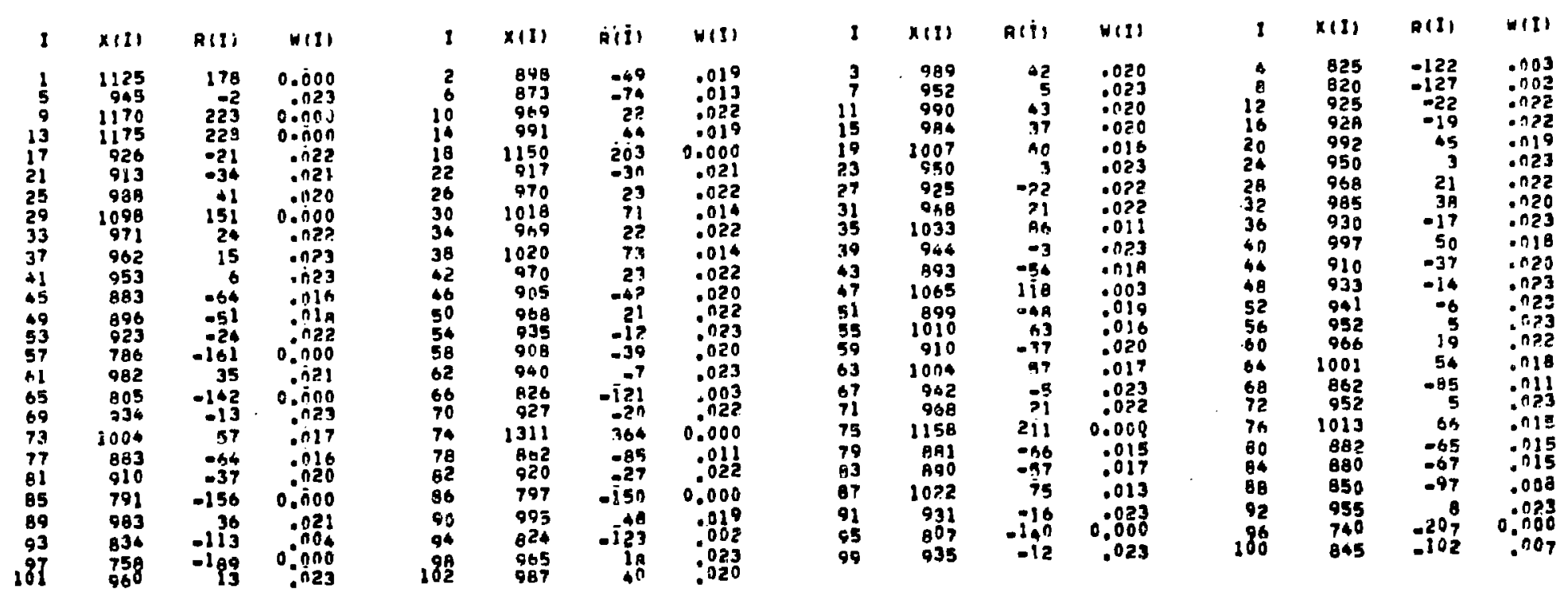

(I) IS THE T-PH ORSERVATIÓN

R(I) IS THE I-PH RESIOUAL FROM THE WEFGHTED MEAN

(II) IS THE WE IGHT GIVEN THE I-TH OBSFAYATION

$N$ IS THE NUMRER OF ORIOINAL OBSERVAT IONS

N. IS THE NUMGER OP OQSERVATIONS WITH NONZERO WEYGHTS 


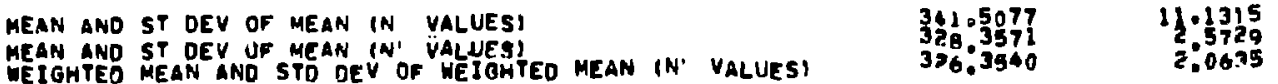

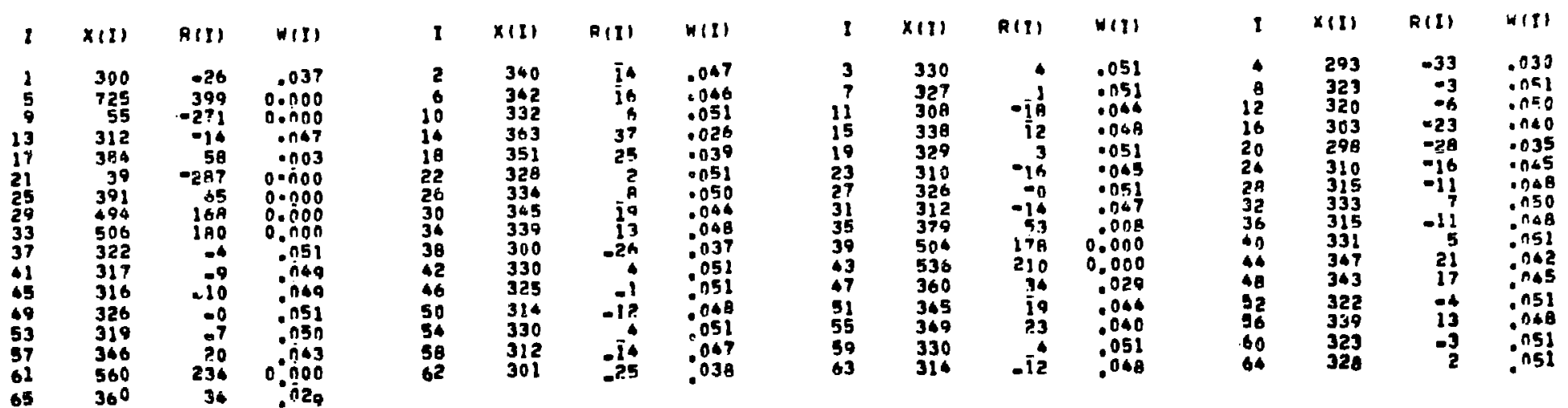

(I) IS THE I-TH OASERVATION

R(I) IS THE I-TM RESTOUAL FROM THE WETGHTEO MEAN

WII IS THE HEIOHT OIVEN THE IOTH OBSFRVATION

N IS THE NUMAER OF ORIGINAL OBSERVATINNS

N. IS THE NUMger OF OASERYATIONS WITH NONZERO WEIGHTS 


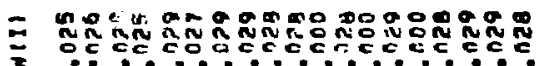

$x \therefore \therefore \therefore$

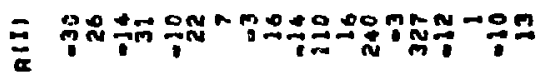

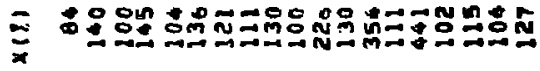

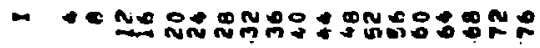

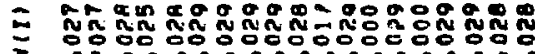



$\overrightarrow{0}+\stackrel{4}{4}$

三

$\sin$

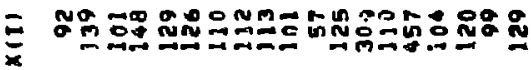

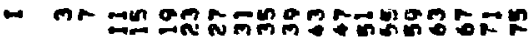

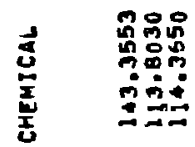

=

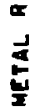

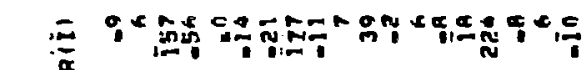

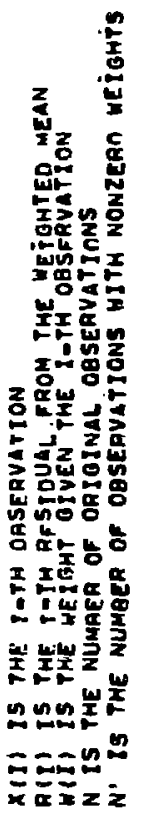

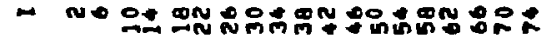

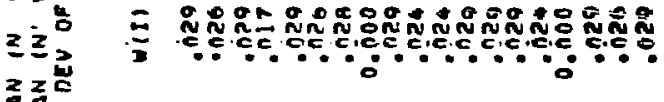

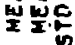

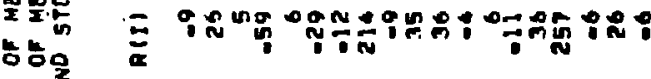

岁岕?

的的㫮

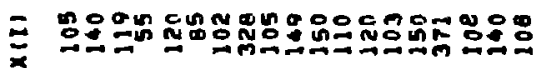

온운은

$\geq \geq 0$

整率严

- 一แ 
MEAN AND ST DEV OF MEAN (N VALUES) MEAN AND ST DEV OF MEAN (N' VALYES!

\begin{tabular}{|c|}
\hline $\begin{array}{l}99.8588 \\
89.838\end{array}$ \\
\hline
\end{tabular}

\begin{tabular}{|c|c|c|c|c|c|c|c|c|c|c|}
\hline I & $x(8)$ & $R(I)$ & $w(1)$ & $I$ & $x(I)$ & $Q(I)$ & $W(I)$ & 1 & $x(1)$ & $R(T)$ \\
\hline $\begin{array}{l}1 \\
5 \\
9\end{array}$ & $\begin{array}{l}103 \\
128 \\
225 \\
216\end{array}$ & $\begin{array}{r}-75 \\
-50 \\
47 \\
38\end{array}$ & $\begin{array}{r}.0122 \\
.020 \\
.020 \\
.0123\end{array}$ & $\begin{array}{r}2 \\
6 \\
26 \\
14\end{array}$ & $\begin{array}{l}146 \\
253 \\
160 \\
145\end{array}$ & $\begin{array}{r}-32 \\
79 \\
-21 \\
-32\end{array}$ & $\begin{array}{l}.024 \\
.011 \\
.027 \\
.024\end{array}$ & $\begin{array}{r}3 \\
7 \\
11 \\
15\end{array}$ & $\begin{array}{l}156 \\
290 \\
173 \\
213\end{array}$ & $\begin{array}{r}-22 \\
112 \\
-5 \\
35\end{array}$ \\
\hline
\end{tabular}

X(I) IS THE TOTH OASERVATION

A(I) IS THE TOTH OASERUATION THE WETGHTED MEAN A(I) IS THE POTH RFSTQUAL FROM THE WEFOHTEO WEA W(I) TS THE WEIOHT OIVEN TIRE I-TH OBSFAVAT N IS THE NUMAFA OF ORISINAL OBSEWVATIANS 
$=905$

$=-m+N$

$\approx$ 우숭

$-0+2$

$=8 \% 8$

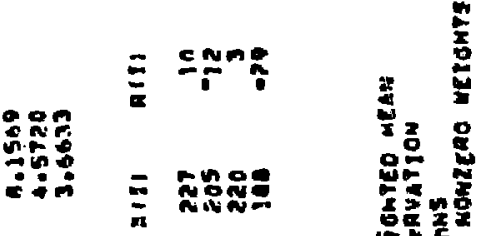

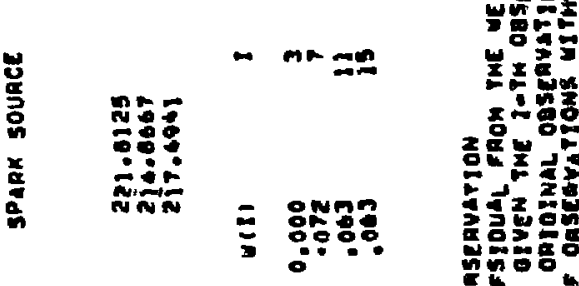

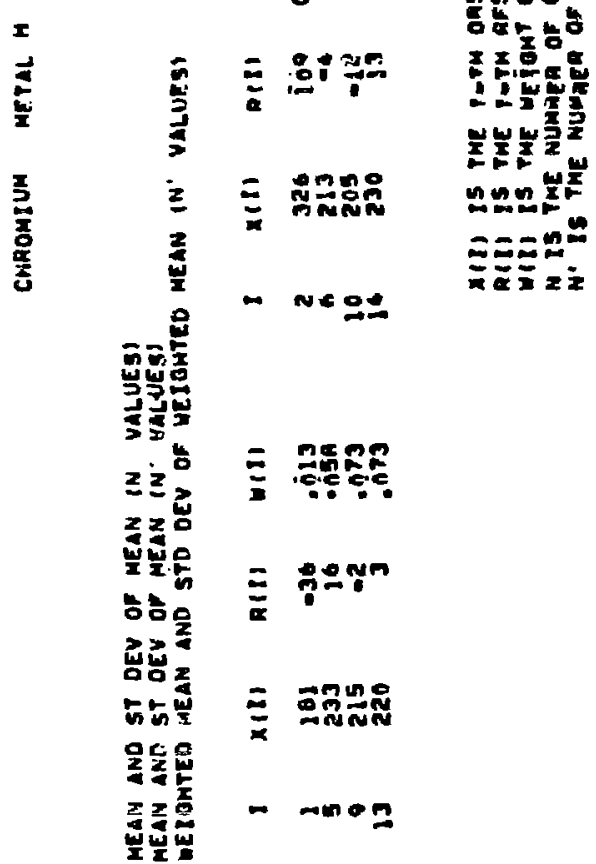




$$
\begin{aligned}
& =575
\end{aligned}
$$

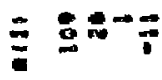

$$
\begin{aligned}
& =858 \\
& -4-\infty
\end{aligned}
$$

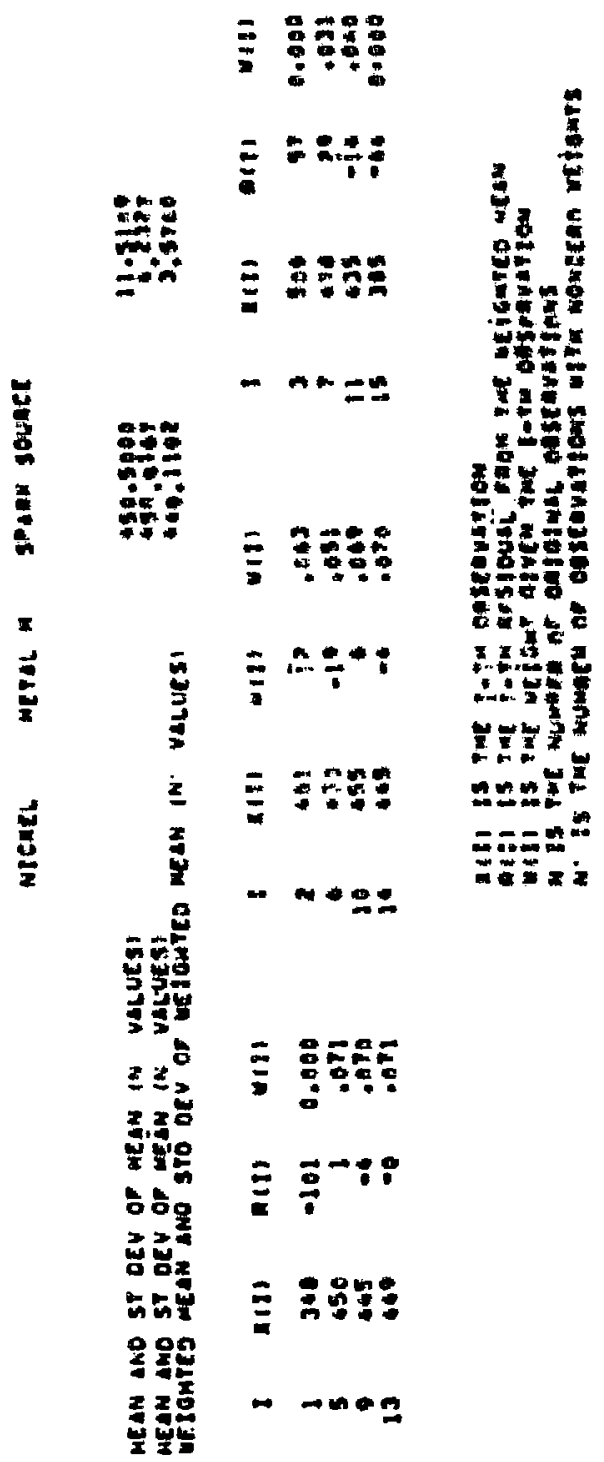




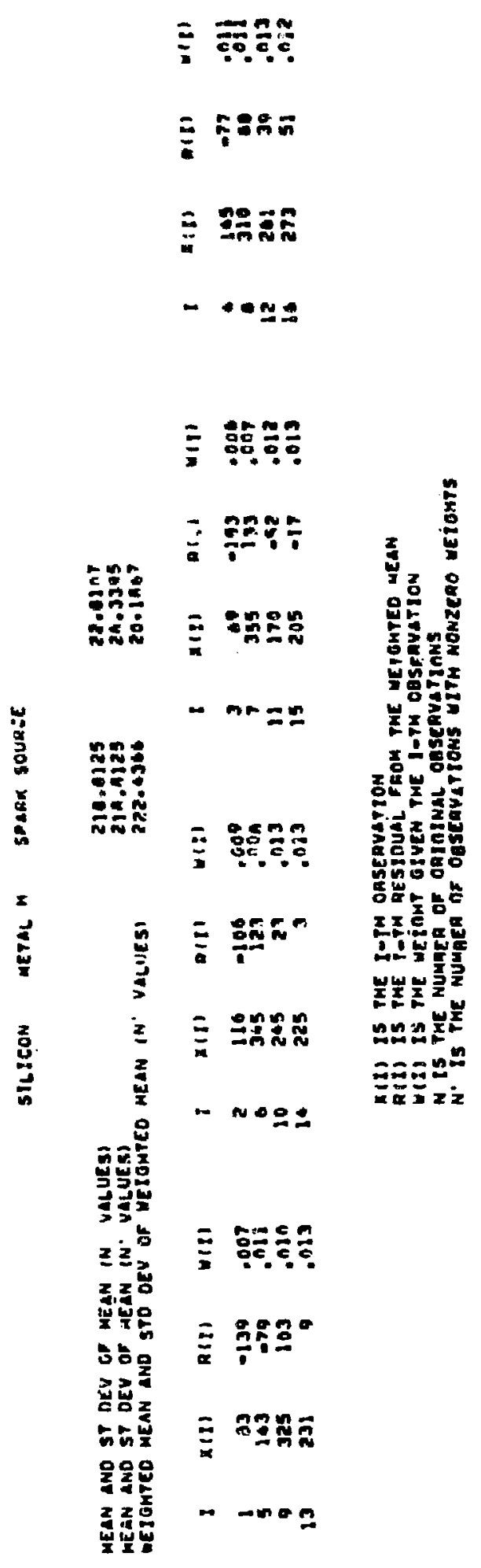


ALUHJNUM METAL P SPARK SOURCE

MEAN AND ST DEV OF MEAN IN VALUES)

MEAN GHTED ST DEV GF MEAN (N. VALUES)

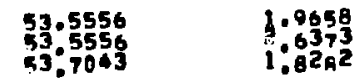

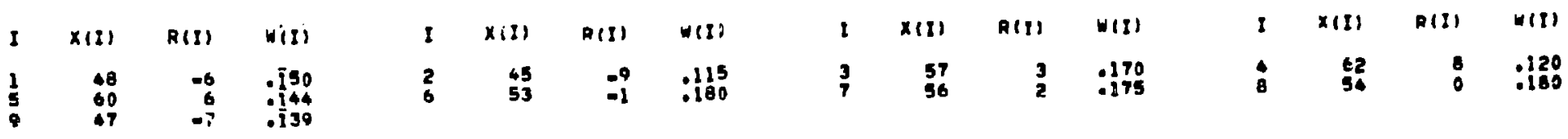

$X(l)$ IS THE I-TH OASEAVATION

R(I) IS THE I-TH AFSIOUAL FAOM THE WE!GHTEO NEAN

W(I) IS THE WEIOHT GIVEN THE I-TH OBSFAVATION

$N$ IS THE NUMAER OF ORIOLNAL OBSERVATIANS

N. IS THE NUMAER OF OBSEAVATIONS WITH NONZEAO WEIGNTS 


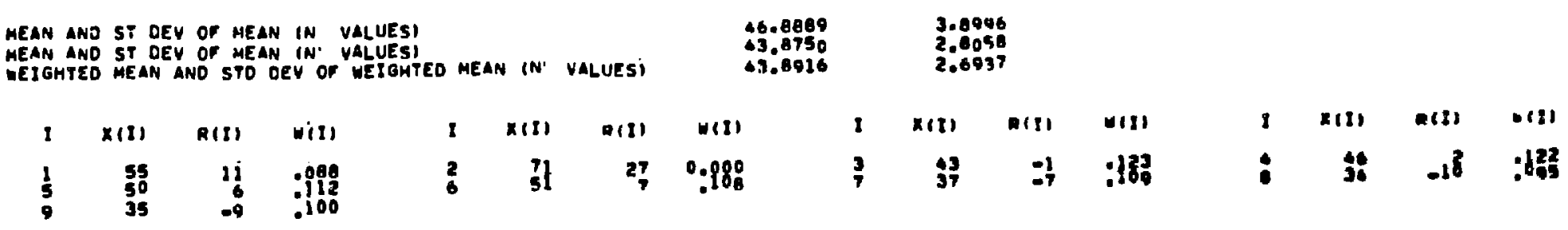

Xit) IS THE I-TM OASEAVATION

RiI) IS THE F-TH RFSJOUAL FROM THE WETGHTEO MEAH

(II) IS THE WE IGHT GIVEN THE I-TH OBSFAVATION

N. IS THE NUMAEA OF ORIGINAL OBSEAVATInNS 
HICKEL METAL D SPAAK SOURCE

MEAN AND ST DEV OF MEAN (N VALUES)

MEAN AND ST DEY OF MFAN (N. VALUES)

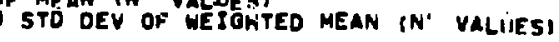

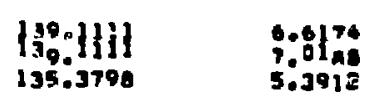

$\begin{array}{rrrr}1 & 155 & 20 & .048 \\ 5 & 143 & 8 & 061\end{array}$

I $x(1)-0(1)-4(I)$

$2 \quad 118 \quad-17 \quad .051$

(I)
051
046

8 มा)

AII)

(I)

$1 \quad 165$

$\rightarrow(2)$

$\cos$

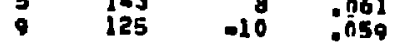

$136 \quad-i \frac{1}{.063}$

- 12

.016
-1059

X(I) IS THE I-ŢH OASERYATíon

A(I) IS THE TOTH QFSTOUAL FAOM THE WETGHTEO WEAN

WII IS TME UEIANT OIVEN THE IOTH OESFAVATION

$N$ IS THE NUMAE? of ốgGinal OBgEavat InNS

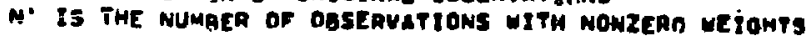


SILICON METAL SPARK SOUACE

MEAN AND ST DEV OF MEAN IN YALUES!

MEAN AND ST OEY OF MEAN IN. VALUES

UE TOHTED MESN AND STO DEV OF UEIOHTEO MEAN (N' VALUES)
32.5000

35.1429
3.46-1

2.5939

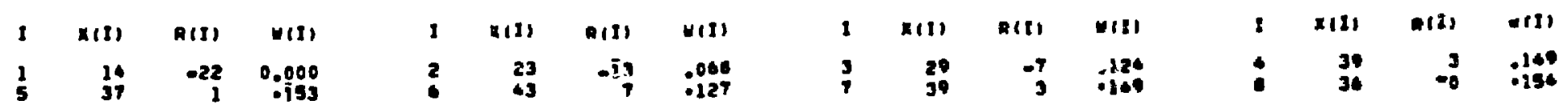

$x(1)$ IS THE TOTH OASEAYATION

R(i) IS THE TOTM RFSTOUAL FAON THE METGHYEO MEAN

M(I) IS THE WEİ̈HT GIVEN TME J-PH OBSFRYATION

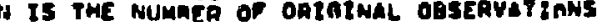

$N$ ' IS THE NUMAEA OF OSEEqUATIONS UITM NOHzEAO METOHTS 
MEAN AWD ST OEV OF MEAN (N VALUES)

MEAM AHD ST OEY OR

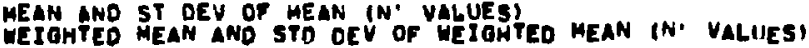

17.1000

16.5558 :372?

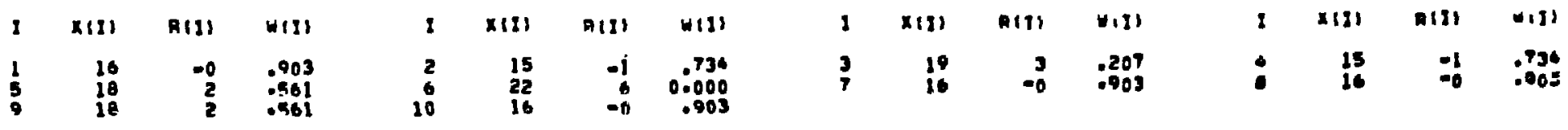

Xily is TWE I-TH OASERVATION

TROM THE MEÝGHTEC MEAN

Wili IS THE WEjOHT OIVEN THE I-TH OESFAYATION

$N$ is THE NUMAEA of OAIOINAL OBSERVATI INS

$N$. IS THE NUMAEA OF OBSEAVATIONS UITH MOMZEAD WEIOHTS 
MEAN AND ST DEV OF MEAN (N VALUESI

MEAN AND ST DEV OF MEAN (N, VALUES)

WEJOHTED MEAN AND STO DEV OF MEIOHTED MEAN (N. VAIUESI

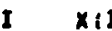

ค(I)

(I)

$\begin{array}{ll}1 & 32 \\ 5 & 36 \\ 9 & 46\end{array}$

$-6 \quad .162$

$\begin{array}{rr}-0 & 1722 \\ -0 & 123\end{array}$

$\begin{array}{rrrr}1 & x(1) & R(I) & w(1) \\ 2 & 30 & -9 & 1122 \\ 8 & 43 & 71 & 1190 \\ 10 & 40 & 51 & .059\end{array}$

38,7000

$3 A .7000$

3ค.0121

1.8910

1.9941

1.5307

P(I) IS THE I-TH OBSERYATION

R(1) IS THE T-TH RESIOUAL FROM THE WETGKTED MEAN

$N$ IS THE NUMAER OF OAIOINAL OBSERVATIONS

N. IS THE NUMAER OF OQSERVATIONS WITH NONZERO WEIGHTS 
NICKEL METAL A SPARK SOUREE

MEAN AND ST DEV OF MEAN IN VALUES)
MEAN AND ST CEV OF MEAN IN' VALUES)
WEIGHTE MEAN AND STD D. OF WEIGHED MEAN (N. VALUESI

\begin{tabular}{|c|c|c|c|c|c|c|c|c|c|c|c|c|c|c|c|}
\hline 1 & $x(I)$ & R(T) & $W(I)$ & I & $x(I)$ & $R(I)$ & $W(\Omega)$ & 9 & $x(z)$ & $R(I)$ & $\forall(I)$ & $I$ & $E(I)$ & $a(2)$ & $W(I)$ \\
\hline 5 & $\begin{array}{r}105 \\
106 \\
86\end{array}$ & $\begin{array}{l}11 \\
12 \\
-8\end{array}$ & $\begin{array}{r}.091 \\
.094 \\
.106\end{array}$ & $\begin{array}{r}2 \\
6 \\
10\end{array}$ & $\begin{array}{r}90 \\
105 \\
88\end{array}$ & $i_{-6}^{\infty}$ & $\begin{array}{r}.122 \\
.091 \\
.115\end{array}$ & $\begin{array}{l}3 \\
7\end{array}$ & $\begin{array}{l}92 \\
93\end{array}$ & $\begin{array}{l}-2 \\
-1\end{array}$ & $\begin{array}{r}.127 \\
.128\end{array}$ & 8 & $\begin{array}{l}98 \\
85\end{array}$ & .9 & $\begin{array}{r}123 \\
.102\end{array}$ \\
\hline
\end{tabular}

$x$ (II) IS PHE Z-TH OASERVATION

R(I) IS PHE I-TH RFSTOLAL FHOM THE WETGHTEO MEAN

WII IS THE WEIOHT OTVEN THE TOTH OBSFAVATION.

$N$ IS THE NUMAFF OF ORTOLNAL OBSERVATIONS

N' IS THE NUMAER OF ORSERVATIONS WITH NONZEPO WETOHTS 
MEAN AND SP OEV OF MEÄN IN VALUES

MEAN ANO ST OEY OF MEAN (N. VALUES)

wE:OMTED MEAN AND STO OEV OF WEIOHTEO MEAN IN' VALUES!

$\begin{array}{ll}36.5000 & 2.7335 \\ 30.1211 & 1.4655\end{array}$

$35.8063 \quad 1.0906$

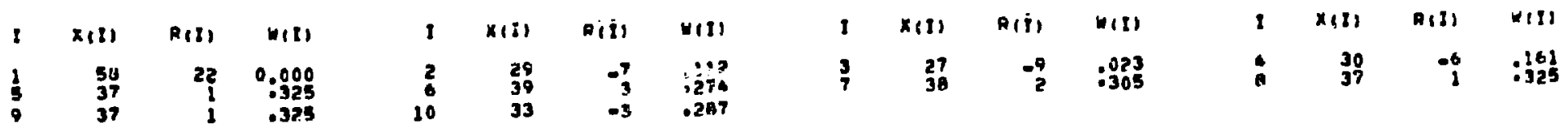

XIII IS THE i-TH OASEgyation

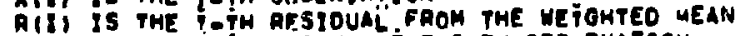

WII) IS THE WE JOKT GIVEN THE I-TA OBSFRYTION

$N$ IS THE NUMAER OF caIOINAL OBSERVATIONS

$N$ ' IS THE NUMGER OF OESERVATIONS WITH NONZERO WEIOHTS 
MEAN ANO ST DEV OF MEÄN IN VALUESI

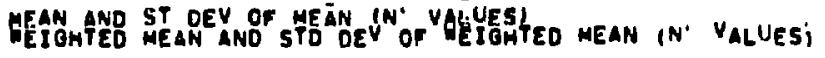

\section{$199.1471 \quad 14.55 A 6$}

$\begin{array}{ll}144.0000 & 2.8527 \\ 1.3 .7951 & 2.4743\end{array}$

\begin{tabular}{|c|c|c|c|c|c|c|c|c|c|c|c|c|c|c|c|}
\hline I & $x(I)$ & Rati & will & 1 & $x(I)$ & Diil & $w(t)$ & $I$ & $x(I)$ & $R(i)$ & wi1) & $I$ & $x(t)$ & $R(l)$ & $W(1)$ \\
\hline $\begin{array}{r}1 \\
5 \\
9 \\
13 \\
17 \\
21 \\
25 \\
29 \\
33\end{array}$ & $\begin{array}{l}553 \\
132 \\
220 \\
167 \\
183 \\
196 \\
197 \\
188 \\
158\end{array}$ & $\begin{array}{r}369 \\
-52 \\
36 \\
-17 \\
-1 \\
10 \\
13 \\
4 \\
-26\end{array}$ & $\begin{array}{r}0.000 \\
0.000 \\
.1222 \\
.051 \\
.0162 \\
.058 \\
.055 \\
.055 \\
.151 \\
.039\end{array}$ & $\begin{array}{l}2 \\
6 \\
10 \\
14 \\
18 \\
22 \\
26 \\
30 \\
30\end{array}$ & $\begin{array}{l}451 \\
122 \\
183 \\
172 \\
199 \\
194 \\
102 \\
165 \\
161\end{array}$ & $\begin{array}{r}267 \\
-62 \\
-11 \\
-12 \\
53 \\
i 1 \\
1 \\
-23\end{array}$ & $\begin{array}{l}0.000 \\
0.000 \\
.062 \\
.057 \\
.061 \\
.050 \\
.059 \\
.062 \\
.043\end{array}$ & $\begin{array}{r}3 \\
7 \\
11 \\
15 \\
19 \\
23 \\
27 \\
37\end{array}$ & $\begin{array}{l}174 \\
169 \\
127 \\
122 \\
131 \\
188 \\
146 \\
186\end{array}$ & $\begin{array}{r}-10 \\
-15 \\
-57 \\
-58 \\
-53 \\
14 \\
2 \\
4\end{array}$ & $\begin{array}{r}.058 \\
.05 \\
0.000 \\
0.000 \\
0.000 \\
.054 \\
.062 \\
.061\end{array}$ & $\begin{array}{l}4 \\
6 \\
12 \\
16 \\
20 \\
24 \\
20 \\
32\end{array}$ & $\begin{array}{l}168 \\
178 \\
126 \\
118 \\
133 \\
196 \\
182 \\
196\end{array}$ & $\begin{array}{r}-16 \\
-6 \\
-58 \\
-66 \\
-51 \\
12 \\
-2 \\
10\end{array}$ & $\begin{array}{l}.053 \\
061 \\
0.000 \\
0.000 \\
0.000 \\
0.700 \\
.756 \\
.742 \\
058\end{array}$ \\
\hline
\end{tabular}

XIII IS THE T-THH OASEAvation

RIII IS PHE FoTM aFSTOUAL FaOM THE WEjOHTEO MEAN

1 II IS THE WEIOHT BIVEN THE I-TH OBSFAVATION

$N$ IS THE NUMAER GF ORIOINAL OBSERVATINAS

$N$ ' IS THE NUMAER OF OBSEAYATIONS WIT NONZERO WEIOHTS 
MEAN ANO ST DEY OF MEAN IN VALUES)

LEIGHTED HEAN AND STO OEV OF WEIGNTEO MEAN (N' VALUES)

\section{$17 \overline{1} .3824$}

17 . 4908

$1.3137 ?$

\begin{tabular}{|c|c|c|}
\hline 1 & $x(I)$ & $R(1)$ \\
\hline $\begin{array}{r}1 \\
5 \\
9 \\
13 \\
17 \\
21\end{array}$ & $\begin{array}{l}176 \\
120 \\
251 \\
196 \\
164 \\
172 \\
171 \\
187 \\
170\end{array}$ & $\begin{array}{r}1 \\
-59 \\
90 \\
25 \\
-7 \\
1 \\
-0 \\
16 \\
-1\end{array}$ \\
\hline
\end{tabular}

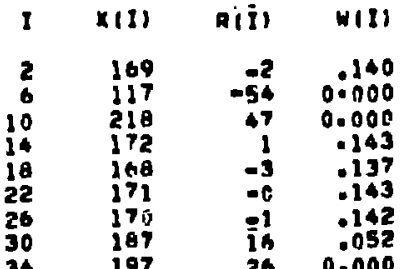

167 in

x(l) IS THE T-IH OASERVATION

R(I) is THE FoTh ReSTOUAL FROM THE METOHTEO MEAN

M(I) IS THE MEjOHT OIVEN THE IOTH OQSFAVATION

$N$ Is TME NUMAFa or ORIOINAL ORSEAVATIANS

$N$ ' IS THE NUMAEa OF OBSEAVATIONS WITH NONZEAS WEIOHTS

$\begin{array}{rrrr}I & x(1) & n(I) & w(1) \\ 1 & 173 & 2 & 1142 \\ 8 & 178 & 7 & 123 \\ 12 & 151 & -20 & 1110 \\ 16 & 146 & -5 & 1129 \\ 20 & 144 & -27 & 0.000 \\ 24 & 169 & -2 & 1140 \\ 28 & 170 & -1 & 1142 \\ .32 & 191 & 20 & 1928\end{array}$


MEAN ANO ST OEV OF MEÄN IN ÜALUESS

MEAN AND ST OEV OF MEAN IN' VALUESI WETED MEAN AND STD DEV OF WEIGHED MEAN IN VALUESI

\subsection{8}

99.7778

\subsection{4}

11,3898

\begin{tabular}{|c|c|c|c|c|c|c|c|c|c|c|c|c|c|c|c|}
\hline$I$ & $x(I)$ & $R(I)$ & $H(I)$ & $I$ & $x(I)$ & R(i) & $H(I)$ & $I$ & $x(I)$ & $R(\bar{I})$ & $\forall(l)$ & $I$ & $x(z)$ & $R(I)$ & $\forall(I)$ \\
\hline $\begin{array}{r}1 \\
5 \\
9 \\
13 \\
17 \\
21 \\
25 \\
3.9 \\
33\end{array}$ & $\begin{array}{r}890 \\
824 \\
850 \\
1028 \\
895 \\
1000 \\
1021 \\
1026 \\
853\end{array}$ & $\begin{array}{l}-26 \\
-92 \\
-66 \\
112 \\
-21 \\
84 \\
105 \\
118 \\
-63\end{array}$ & 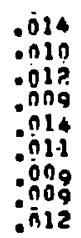 & $\begin{array}{l}2 \\
6 \\
10 \\
36 \\
16 \\
22 \\
28 \\
38 \\
34\end{array}$ & $\begin{array}{r}836 \\
2120 \\
931 \\
1110 \\
935 \\
858 \\
1028 \\
909 \\
897\end{array}$ & $\begin{array}{r}-82 \\
204 \\
195 \\
194 \\
19 \\
-515 \\
112 \\
-10\end{array}$ & $\begin{array}{l}.011 \\
0001 \\
.014 \\
.002 \\
0014 \\
0013 \\
.009 \\
0014 \\
.014\end{array}$ & $\begin{array}{l}3 \\
7 \\
11 \\
15 \\
19 \\
23 \\
27 \\
31 \\
35\end{array}$ & $\begin{array}{r}847 \\
915 \\
840 \\
796 \\
999 \\
991 \\
1004 \\
699 \\
909\end{array}$ & $\begin{array}{r}-49 \\
-1 \\
-7 y \\
-1>2 \\
83 \\
75 \\
98 \\
-19 \\
-7\end{array}$ & 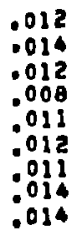 & $\begin{array}{l}0 \\
12 \\
16 \\
20 \\
20 \\
26 \\
32 \\
.36\end{array}$ & $\begin{array}{r}1044 \\
894 \\
882 \\
827 \\
910 \\
997 \\
965 \\
825 \\
942\end{array}$ & $\begin{array}{r}128 \\
-22 \\
-36 \\
-89 \\
-6 \\
81 \\
-88 \\
-91 \\
26\end{array}$ & $\begin{array}{l}.000 \\
.014 \\
014 \\
011 \\
0.011 \\
0.11 \\
011 \\
011 \\
0.014\end{array}$ \\
\hline
\end{tabular}

$x(I)$ ts THE [-TH OBSERYATIION

Rili IS PHE POTH RESIDUAL FROM THE WEjGHTEO MEAN

WII IS THE WEIOHT OIVEN THE I-TH OBSFRVATION

$N$ IS THE NUMRER OF OALOLNAL OBSERVATINNS

N IS THE NUMRER OF OGSERVATIONS WITH NONZERO WEIOHTS 
MEAN AND ST OEV OF MEAN IN VALUESI MEAN AND ST DEV DF MEAN IN' VALUESI

\subsection{6} 47.6061
47.4692

\subsection{7}

0.1531

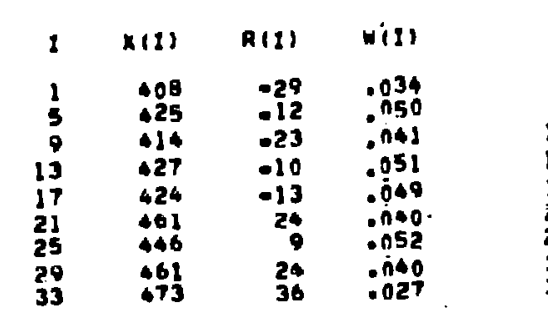

\begin{tabular}{|c|c|}
\hline$R(i)$ & $W(I)$ \\
\hline $\begin{array}{r}-64 \\
-17 \\
-23 \\
1.3 \\
-3 \\
-14 \\
-3.3 \\
-14\end{array}$ & $\begin{array}{l}0.000 \\
.046 \\
.041 \\
.050 \\
.053 \\
.048 \\
.029 \\
.048 \\
.052\end{array}$ \\
\hline
\end{tabular}

$\begin{array}{rrrr}7 & x(1) & 0(i) & w(I) \\ 3 & 456 & 21 & .043 \\ 7 & 425 & -12 & .050 \\ 11 & 412 & -75 & .030 \\ 15 & 380 & -57 & .001 \\ 19 & 434 & -3 & .053 \\ 23 & 457 & 20 & .046 \\ 27 & 142 & 5 & .053 \\ 31 & 439 & 2 & 0053 \\ 35 & 465 & 6 & .052\end{array}$

\begin{tabular}{|c|c|c|c|}
\hline 1 & $x(2)$ & $A(I)$ & $v(1)$ \\
\hline $\begin{array}{l}4 \\
12 \\
16 \\
20 \\
24\end{array}$ & $\begin{array}{l}496 \\
456 \\
412 \\
378 \\
460 \\
465 \\
451\end{array}$ & $\begin{array}{r}57 \\
19 \\
-25 \\
059 \\
23 \\
8 \\
14\end{array}$ & $\begin{array}{r}. n 00 \\
. n 45 \\
.138 \\
0.000 \\
.041 \\
. n 52 \\
.009\end{array}$ \\
\hline 32 & $\begin{array}{l}353 \\
471\end{array}$ & -34 & $\begin{array}{r}0.100 \\
.029\end{array}$ \\
\hline
\end{tabular}

XII) IS THE I-TH OASERYAYTION

(II) TS THE GETOHT GIVEN THE IOTH OBSFAVATION

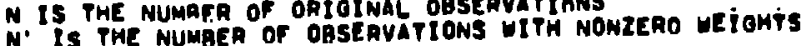




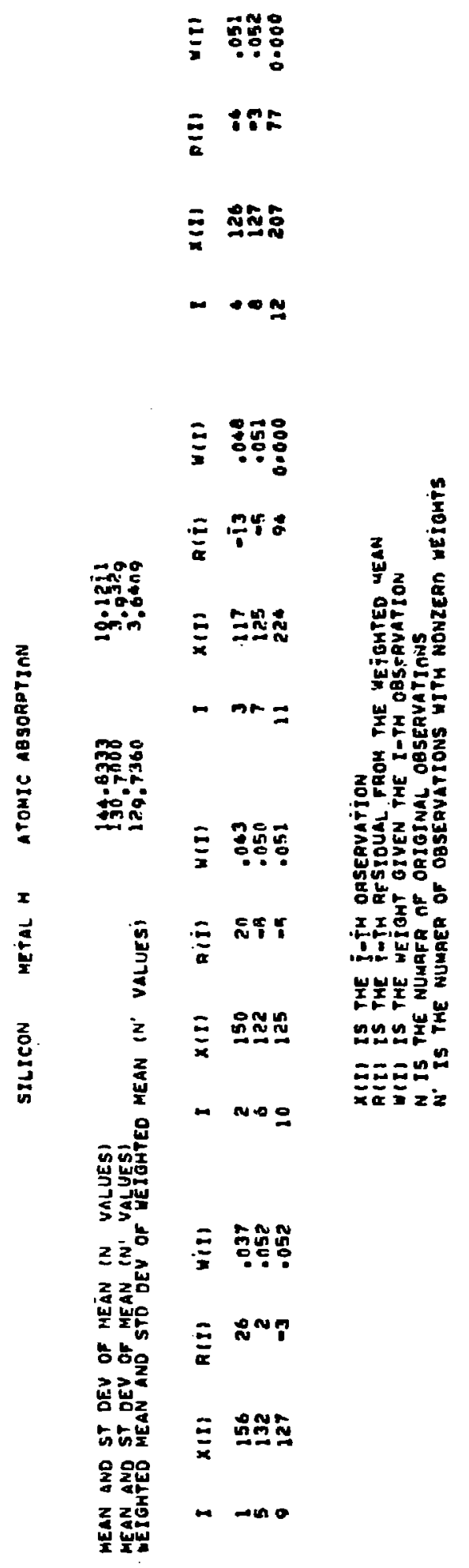




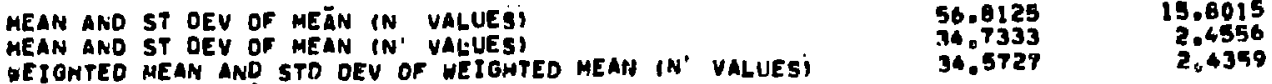

\begin{tabular}{|c|c|c|c|c|c|c|c|c|c|c|c|c|c|c|c|}
\hline$I$ & $x(1)$ & $F(t)$ & wit) & $I$ & $x(2)$ & Q(II) & $W(I)$ & I & $x(I)$ & A(t) & $w(I)$ & $I$ & $x(I)$ & $a(t)$ & $\|(I)$ \\
\hline $\begin{array}{l}1 \\
5 \\
9 \\
13 \\
17 \\
23 \\
25 \\
20\end{array}$ & $\begin{array}{r}21 \\
23 \\
51 \\
69 \\
35 \\
24 \\
45 \\
653\end{array}$ & $\begin{array}{r}-14 \\
012 \\
16 \\
14 \\
0 \\
-31 \\
10 \\
118\end{array}$ & $\begin{array}{l}.034 \\
0.034 \\
.033 \\
.034 \\
.035 \\
.035 \\
.035 \\
0.035 \\
0.000\end{array}$ & $\begin{array}{l}2 \\
6 \\
10 \\
16 \\
16 \\
22 \\
26 \\
30\end{array}$ & $\begin{array}{r}19 \\
21 \\
53 \\
53 \\
31 \\
22 \\
36 \\
323\end{array}$ & 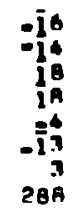 & $\begin{array}{l}.036 \\
0034 \\
0033 \\
0033 \\
0035 \\
0034 \\
0035 \\
0.000\end{array}$ & $\begin{array}{r}3 \\
7 \\
11 \\
15 \\
19 \\
23 \\
27 \\
31\end{array}$ & $\begin{array}{l}28 \\
91 \\
49 \\
29 \\
28 \\
21 \\
21 \\
56\end{array}$ & $\begin{array}{r}-7 \\
16 \\
16 \\
-6 \\
-7 \\
-16 \\
-14 \\
21\end{array}$ & $\begin{array}{l}.035 \\
.033 \\
.034 \\
.039 \\
.039 \\
.036 \\
.034 \\
.032\end{array}$ & $\begin{array}{l}\$ \\
12 \\
18 \\
20 \\
26 \\
28 \\
32\end{array}$ & $\begin{array}{l}25 \\
52 \\
51 \\
32 \\
23 \\
23 \\
27 \\
51\end{array}$ & $\begin{array}{r}-10 \\
17 \\
16 \\
-3 \\
-12 \\
-12 \\
-18 \\
-16\end{array}$ & $\begin{array}{l}.035 \\
0.023 \\
0.033 \\
.075 \\
.034 \\
01034 \\
.033 \\
.033\end{array}$ \\
\hline
\end{tabular}

X(I). IS THE I-THH ORSERVATION

R(I) IS THE T-TH RESTOUAL FROM THE HETOHTEO MEAN

WIII IS THE WEIOHT O!VEN THE IATH OBSFRVATION

$N$ IS THE NUMRER OF ORIGINAL OBSERYATIONS

' IS THE NUMAER OF OBSERVATIONS WITK NONZERO WEIONTS 
ChROMIUM METAL R ATOMJC ABSORPTION

MEAN ANO ST OEY OF MEÃN IN YALUESI

WEIOHTED MEAN AND STO DEV OF WEIGHTEO MEAN IN' VALUESI
$69.6765 \quad 1.2984$

$69,6765 \quad 1.33 A 3$

$\begin{array}{rrrr}I & x(I) & R(i) & \text { wit } \\ 1 & 41 & -8 & .12 \\ 5 & 37 & -12 & 1775 \\ 9 & 53 & 4 & 158 \\ 13 & 59 & 10 & .098 \\ 17 & 51 & 2 & 168 \\ 21 & 50 & 1 & 171 \\ 25 & 46 & -3 & 165 \\ 29 & 61 & 12 & 177 \\ 33 & 39 & -10 & 100\end{array}$

\begin{tabular}{|c|c|c|c|}
\hline 1 & $x(1)$ & Riil & $H(I)$ \\
\hline $\begin{array}{r}2 \\
6 \\
10 \\
14 \\
16 \\
22 \\
26 \\
38 \\
34\end{array}$ & $\begin{array}{l}41 \\
40 \\
53 \\
59 \\
49 \\
55 \\
43 \\
63 \\
40\end{array}$ & $\begin{array}{r}-A \\
-9 \\
\text { in } \\
n \\
6 \\
-6 \\
14 \\
-9\end{array}$ & $\begin{array}{l}124 \\
112 \\
158 \\
098 \\
0172 \\
1142 \\
1144 \\
1147 \\
112\end{array}$ \\
\hline
\end{tabular}

$\begin{array}{rrrr}I & \times(1) & R(i) & W(1) \\ 3 & 50 & 1 & : 171 \\ 7 & 50 & 1 & 171 \\ 11 & 92 & 3 & : 164 \\ 15 & 50 & 1 & 171 \\ 19 & 56 & 77 & 1132 \\ 23 & 63 & 14 & 947 \\ 27 & 42 & -7 & 1136 \\ 31 & 48 & -1 & 171\end{array}$

$\begin{array}{rr}1 & \times(1) \\ 4 & 56 \\ 12 & 51 \\ 12 & 50 \\ 20 & 42 \\ 24 & 49 \\ 39 & 65 \\ 32 & 46\end{array}$

Q(I) $\forall(1)$

X (I) IS THE I-TH OASERVATION

(I) IS THE WE jOHT GIVEN THE I-TH OBSFAVATION

$N$ IS THE NUMAFR OF ORIGINAL OBSERVATIONS

$N$ ' IS THE NUMRER OF OBSERVATIONS WITH NONZERO WEIGHTS 
MEAN AND ST DEV OF MË̈N IN VALLESS

MEAN AND ST DEV OF MEAN IN. VALUES)

WEJGKTED MEAN ANE STD DEV OF MEIONTEO MEAN (N' VALLUES)

\section{$123.5556 \quad 5.6042$}

$\begin{array}{ll}114.0312 & 2.4753 \\ 112.0587 & 2.1336\end{array}$

\begin{tabular}{|c|c|c|c|c|c|c|c|c|c|c|c|c|c|c|c|}
\hline I & $x(1)$ & A(I) & wits & I & $x(1)$ & Diji & $w(J)$ & 1 & $x(1)$ & $R(1)$ & $\forall(1)$ & 1 & $x(1)$ & $R(I)$ & WII \\
\hline $\begin{array}{r}\frac{1}{5} \\
9 \\
23 \\
17 \\
21 \\
25 \\
29 \\
33\end{array}$ & $\begin{array}{l}106 \\
136 \\
111 \\
111 \\
120 \\
104 \\
260 \\
150 \\
122\end{array}$ & $\begin{array}{r}-7 \\
23 \\
-2 \\
-2 \\
7 \\
-9 \\
156 \\
37 \\
9\end{array}$ & 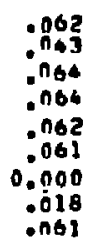 & $\begin{array}{r}2 \\
6 \\
10 \\
10 \\
18 \\
22 \\
26 \\
30 \\
34\end{array}$ & $\begin{array}{l}98 \\
122 \\
111 \\
126 \\
115 \\
109 \\
202 \\
143 \\
121\end{array}$ & $\begin{array}{r}-i s \\
9 \\
-? \\
13 \\
? \\
-5 \\
89 \\
30 \\
\text { n }\end{array}$ & $\begin{array}{r}0055 \\
0.061 \\
0.06 \\
0.057 \\
.066 \\
0.063 \\
0.000 \\
.031 \\
.061\end{array}$ & $\begin{array}{l}3 \\
7 \\
13 \\
15 \\
19 \\
23 \\
27 \\
31 \\
35\end{array}$ & $\begin{array}{c}122 \\
92 \\
138 \\
127 \\
94 \\
108 \\
105 \\
162 \\
105\end{array}$ & $\begin{array}{r}9 \\
-21 \\
5 \\
14 \\
-19 \\
-5 \\
-8 \\
49 \\
-8\end{array}$ & $\begin{array}{r}.861 \\
0.047 \\
0.063 \\
.054 \\
0080 \\
0.063 \\
0.062 \\
0.000 \\
.062\end{array}$ & $\begin{array}{r}6 \\
6 \\
17 \\
16 \\
26 \\
26 \\
28 \\
32 \\
36\end{array}$ & $\begin{array}{r}138 \\
128 \\
115 \\
908 \\
208 \\
98 \\
266 \\
206\end{array}$ & $\begin{array}{r}-17 \\
10 \\
2 \\
2 \\
-19 \\
-5 \\
-15 \\
53 \\
-7\end{array}$ & 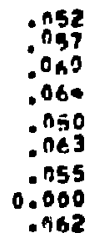 \\
\hline
\end{tabular}

$x(1)$ is the $j-j$ H orseryajion

Q(i) is THE T-TH RESTOUAi SROM THE WE IGHTED MEAN

W(I) IS THE WEjOHT GIVEN THE I-TH OBSFRYATION

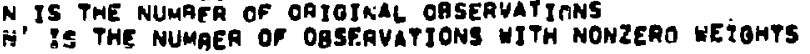


NICKEL MEtál a atOMIC absoliption

MEAN AND ST OEV OF MEÁN IN ÜALUE\$!

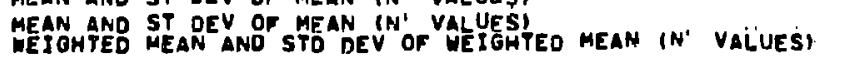

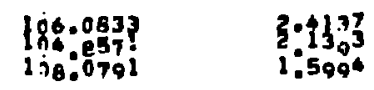

\begin{tabular}{|c|c|c|c|c|c|c|c|c|c|c|c|c|c|c|c|}
\hline$t$ & $x(1)$ & $R(t)$ & $y(1)$ & I & $x(I)$ & R(i) & $W(I)$ & 1 & $x(1)$ & $A(\bar{I})$ & $W(I)$ & $I$ & $x:(1)$ & $R(I)$ & $W(I)$ \\
\hline $\begin{array}{r}1 \\
5 \\
9 \\
13 \\
17 \\
21 \\
25 \\
29 \\
33\end{array}$ & $\begin{array}{r}80 \\
90 \\
117 \\
115 \\
121 \\
106 \\
149 \\
103 \\
91\end{array}$ & $\begin{array}{r}-28 \\
-18 \\
9 \\
7 \\
13 \\
-4 \\
41 \\
-17 \\
-17\end{array}$ & 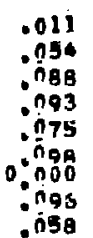 & $\begin{array}{r}2 \\
6 \\
10 \\
14 \\
18 \\
22 \\
26 \\
30 \\
34\end{array}$ & $\begin{array}{r}60 \\
90 \\
117 \\
115 \\
125 \\
116 \\
116 \\
102 \\
80\end{array}$ & $\begin{array}{r}-\sum_{2} A \\
-1 A \\
9 \\
7 \\
77 \\
9 \\
A \\
-2 A \\
-21\end{array}$ & $\begin{array}{l}.011 \\
.054 \\
.088 \\
.093 \\
.059 \\
.090 \\
.090 \\
.095 \\
.045\end{array}$ & $\begin{array}{l}2 \\
71 \\
19 \\
19 \\
23 \\
27 \\
31 \\
35\end{array}$ & $\begin{array}{l}110 \\
106 \\
117 \\
116 \\
116 \\
104 \\
812 \\
112 \\
103\end{array}$ & $\begin{array}{r}2 \\
-2 \\
9 \\
8 \\
6 \\
-36 \\
-76 \\
-5\end{array}$ & $\begin{array}{l}100 \\
100 \\
1080 \\
.090 \\
.095 \\
.098 \\
.098 \\
.098 \\
.096\end{array}$ & $\begin{array}{r}6 \\
12 \\
16 \\
20 \\
24 \\
28 \\
32 \\
36\end{array}$ & $\begin{array}{r}104 \\
109 \\
128 \\
116 \\
110 \\
98 \\
93 \\
102 \\
99\end{array}$ & $\begin{array}{r}-4 \\
1 \\
8 \\
8 \\
2 \\
-20 \\
-26 \\
-6 \\
-9\end{array}$ & $\begin{array}{l}.098 \\
.101 \\
.090 \\
.090 \\
.100 \\
.984 \\
.998 \\
.095 \\
.099\end{array}$ \\
\hline
\end{tabular}

$x(1)$ IS THE i-ïH ORSFRVAỸION

RIII IS THE TOTH RESTOUA FROM THE WEF̈OHTED MEAN

W(I) IS THE WEIOHT GIVEN THE I-TH OBSFAVATION

$N$ IS THE NUMAFR OF ORIOINAL OBSERVATIONS

$N^{\circ}$. IS THE NUMAER OF OBSERVATIONS WITH NONZERO WEIOHTS 
mEAN AHD ST DEV OF MEÁN IN VALUESI

MEAN AND ST DEV OF MEAN IN' VALUES?
WEIOHTEO MEAN AND STO OEV OF HETOHTED MEAN IN' VALUFSI

32.5000

32.3000

32.5 a3
1.2225
1.2816

.9210

\begin{tabular}{|c|c|c|c|c|c|c|c|c|c|c|c|c|c|c|}
\hline I & $x(I)$ & a(ii) & $\|(I)$ & 1 & $x(1)$ & 的汶 & W(I) & $I$ & $x(1)$ & $R(i)$ & $W(I)$ & $I$ & $n(x)$ & $R(I)$ \\
\hline $\begin{array}{l}1 \\
5 \\
9\end{array}$ & $\begin{array}{l}26 \\
28 \\
38\end{array}$ & -7 & $\begin{array}{l}074 \\
.776 \\
.153\end{array}$ & $\begin{array}{r}2 \\
6 \\
10\end{array}$ & $\begin{array}{l}34 \\
33 \\
34\end{array}$ & $\begin{array}{l}1 \\
1 \\
1\end{array}$ & $\begin{array}{r}379 \\
3989 \\
379\end{array}$ & 3 & 38 & 5 & 1353 & 4 & $\begin{array}{l}31 \\
29\end{array}$ & -2 \\
\hline
\end{tabular}

X11) Is the í-ịH OASERYATín

RII IS Ti. T-in RESTOUAL From TKE WETOHTEO MEAN

W(I) IS THE WEIOHT OTVEN THE I-TH OBSFAVATION

$M$ is TME NUmAFR of ORIOINAL OBSERVATIANS

$N$. IS THE MUMAEQ OF DSSERVATIONS WITY NONZEAN WETOHTS 